\title{
Krzysztof Buchowski
}

https://orcid.org/0000-0003-3222-1994

Wydział Historii i Stosunków Międzynarodowych Uniwersytetu w Białymstoku

\section{Litwa 1993: kluczowy rok niepodległości}

Zarys treści: W 1993 r. na Litwie doszło do serii ważnych wydarzeń. W wyniku wyborczego zwycięstwa postkomunistycznej lewicy scena polityczna uległa polaryzacji. Porażka przypieczętowała dekompozycję Sajudisu i przyspieszyła proces klarowania się centroprawicowych stronnictw politycznych. Parlamentarna opozycja potrafiła jednak skutecznie blokować władzę. Latem 1993 udało się zakończyć ewakuację rosyjskich żołnierzy z Litwy. W kraju doszło również do buntu formacji paramilitarnej, a także miała miejsce wizyta papieża Jana Pawła II. Ostatecznie pod koniec roku pod wpływem widma zagrożenia rosyjskiego oba czołowe litewskie bloki polityczne zdecydowały się na kompromis na gruncie polityki zagranicznej.

Outline of content: In 1993, a series of significant events took place in Lithuania. As a result of the electoral victory of the post-communist leftist party, the political scene became polarized. The defeat sealed the decomposition of Sajudis and accelerated the process of clarifying the centre-rightist political parties. However, the parliamentary opposition was able to block the authorities successfully. In the summer of 1993, the evacuation of Russian soldiers from Lithuania was completed. There was also a paramilitary rebellion in the country, and a visit of Pope John Paul II took place. Ultimately, at the end of the year, under the influence of the spectre of the Russian threat, both leading Lithuanian political blocks decided to compromise on the grounds of foreign policy.

Słowa kluczowe: Litwa, Sajudis, wybory, prezydent, postkomuniści, ewakuacja rosyjskich wojsk, bunt ochotników, traktat z Polską

Keywords: Lithuania, Sajudis, elections, president, post-communists, evacuation of Russian troops, volunteer revolt, treaty with Poland

\section{Uwagi wstępne}

W celu uporządkowania wiedzy o przeszłości historycy niejednokrotnie stosują rachubę czasu odmienną od ściśle kalendarzowego porządku. W takich sytuacjach początek lub koniec epoki zwykle bywa wyznaczany przez wypadki, których skutki 
istotnie wpłynęły na bieg dziejów. Opisany zabieg na ogół jest stosowany przez badaczy starożytności, mediewistów i nowożytników, ponieważ znaczenie niektórych wydarzeń można określić dopiero z dłuższej perspektywy czasowej. Nie ma jednak innych przeciwskazań do użycia podobnych sposobów także przez historyków czasów najnowszych (przykładowo coraz bardziej ugruntowuje się przekonanie o „krótkim wieku dwudziestym” w dziejach świata zachodniego: epoce zapoczątkowanej konferencją paryską i traktatem wersalskim 1919 r., a zakończonej rozwiązaniem ZSRR w 1991 r.).

W niniejszym artykule przedstawiono analizę sekwencji wydarzeń, do których doszło w „długim roku 1993” na Litwie. Z szerszej perspektywy można zaryzykować tezę, że miały one kluczowy charakter w dziejach państwa i społeczeństwa, znaczeniem dorównując wcześniejszemu o kilka lat przywróceniu niepodległości. W następstwie opisywanych zdarzeń nie tylko wyklarowała się krajowa scena polityczna, ale przede wszystkim ukształtował zasadniczy kierunek rozwoju państwa w nowej rzeczywistości międzynarodowej. Litwa przyjęła wówczas konsekwentną opcję prozachodnią, mimo różnych przeszkód realizowaną w następnych dekadach.

Jeśli trzymać się wspomnianej wyżej konwencji (a także przy założeniu zachowania proporcji merytorycznych i poszanowania zastrzeżeń metodologicznych), należy zauważyć, że rok 1993 na Litwie był wyjątkowo długi, zdecydowanie wykraczając poza ramy kalendarzowej chronologii. Rozpoczął się bowiem przyspieszonymi wyborami parlamentarnymi przeprowadzonymi na przełomie października i listopada 1992 r. Wyborczą klęskę poniósł wówczas ruch, któremu Litwa zawdzięczała odzyskanie wolności po latach przynależności do ZSRR. Zwyciężyło ugrupowanie będące do niedawna częścią Komunistycznej Partii Związku Radzieckiego (KPZR). Litewski „długi rok 1993” zakończył się w pierwszych dniach stycznia 1994 r., kiedy wybrany w powszechnych wyborach prezydent, a zarazem niedawny przywódca komunistyczny, złożył oficjalny wniosek o członkostwo Litwy w NATO.

\section{Odzyskanie niepodległości.}

\section{Dominacja Sajudisu na scenie politycznej}

W połowie lat osiemdziesiątych XX w. nowy sekretarz generalny KPZR Michaił Gorbaczow zainicjował tzw. przebudowę (pieriestrojkę) systemu komunistycznego. Doraźnym efektem było złagodzenie cenzury i zmniejszenie represyjności reżimu, sprzyjające uwolnieniu aktywności społecznej. W republikach nadbałtyckich ZSRR władze zainicjowały tworzenie ruchów wsparcia pieriestrojki. W czerwcu $1988 \mathrm{r}$. zorganizował się Litewski Ruch na Rzecz Przebudowy (Lietuvos Persitvarkymo Sąjūdis, następnie działający pod nazwą Lietuvos Sąjūdis, w uproszczonej polskiej wersji zwany dalej Sajudisem). Przywódcą został bezpartyjny muzykolog Vytautas Landsbergis. Ruch szybko zyskał ogromną popularność i masowy charakter. Do Sajudisu wstąpiło m.in. wielu członków partii komunistycznej. W październiku 
1988 r. na pierwszego sekretarza Komitetu Centralnego Komunistycznej Partii Litwy (KPL będąca składową częścią KPZR) wybrano reformatorsko nastawionego Algirdasa Brazauskasa, cieszącego się wówczas poparciem zarówno Moskwy, jak i Sajudisu.

Nastroje mieszkańców Litwy szybko ulegały jednak radykalizacji, a postulaty Sajudisu ewoluowały. Początkowe hasła naprawy komunizmu i rozszerzenia samodzielności republiki w ramach ZSRR wkrótce zostały zastąpione żądaniami przywrócenia pełnej niepodległości. Mimo gniewnych pomruków z Moskwy, również KPL odłączyła się od KPZR, a następnie postanowiła także odciąć się od ideologii komunistycznej. Zmieniła nazwę na Litewska Demokratyczna Partia Pracy (LDPP, lit. Lietuvos demokratine darbo partija) i zadeklarowała wierność ideom demokratycznego socjalizmu. Na początku 1990 r. w wyborach do Rady Najwyższej (parlamentu) republiki Sajudis odniósł tryumfalne zwycięstwo. Przewodniczącym Rady został Landsbergis, który dążył do jak najszybszego ogłoszenia niepodległości. „Akt przywrócenia niepodległości Państwa Litewskiego" przegłosowano 11 marca 1990 r. Pod dokumentem znalazły się podpisy zdecydowanej większości deputowanych, w tym Brazauskasa.

Rada Najwyższa uchwaliła tymczasową konstytucję, skonstruowaną częściowo jeszcze wedle wzorów sowieckich, i powołała nowy rząd. W latach 1990-1991 litewska scena polityczna została zdominowana przez jednego aktora, przewodniczącego Rady Landsbergisa, który pełnił jednocześnie obowiązki głowy państwa. Landsbergis stał się symbolem zmagań o niepodległość Litwy i autentycznym przywódcą narodu. Moskwa usiłowała złamać zbuntowaną republikę za pomocą blokady gospodarczej. Kreml podjął także próbę zbrojnej interwencji. W styczniu 1991 r. na ulicach Wilna rozegrał się dramat, śmierć od kul i pod gąsienicami czołgów poniosło kilkanaście osób. Kilka miesięcy później, w sierpniu 1991 r., w następstwie załamania się moskiewskiego puczu Janajewa, niepodległość Litwy (oraz pozostałych państw bałtyckich) została ostatecznie uznana przez ZSRR i całą społeczność międzynarodową.

Jednak entuzjastyczne nastroje spowodowane odzyskaniem wolności szybko wyparowały. W okresie od jesieni 1991 do końca 1992 r. społeczne koszty firmowanej przez Sajudis ekonomicznej i politycznej transformacji były ogromne. Pospiesznie przeprowadzana reprywatyzacja gospodarki skutkowała tyleż subiektywnym, co powszechnym odczuciem krzywdy i niesprawiedliwości. Upadały kolejne przedsiębiorstwa. Pojawiło się zjawisko bezrobocia, wcześniej niemal nieznane. Spadały dochody ludności, rosły koszty utrzymania. Uaktywniła się zorganizowana przestępczość, żerująca na słabości tworzących się dopiero struktur policji i wojska. Litwa jednocześnie pozostawała całkowicie zależna od dostaw surowców energetycznych z ZSRR (a od końca 1991 r. z Rosji). Moskwa wykorzystywała sytuację, domagając się opłat rynkowych, znacznie wyższych niż dotychczasowe obowiązujące w ZSRR. Nierzadko wstrzymywano dostawy pod pretekstem zalegania przez Wilno z opłatami. W efekcie rosły ceny niemal wszystkich produktów, a zimą 
mieszkańcy Litwy marzli w niedogrzanych mieszkaniach. Wskaźniki gospodarcze i średni poziom życia ludności obniżyły się do stanu z początku lat sześćdziesiątych ${ }^{1}$.

Nawet świeżo odzyskana suwerenność państwa nie wydawała się ugruntowana. W kraju nadal stacjonowało kilkadziesiąt tysięcy żołnierzy dawnej Armii Radzieckiej, teraz już oficjalnie rosyjskiej. Dopiero we wrześniu 1992 r., dzięki politycznemu wsparciu rządów państw Zachodu, udało się uzgodnić z Rosją terminarz ewakuacji. Niemal natychmiast okazało się jednak, że rosyjska strona wcale nie traktuje porozumienia $\mathrm{z}$ Litwinami $\mathrm{w}$ zobowiązujący sposób, a jedynie uznaje za preliminarz ${ }^{2}$. Postępy wycofywania wojsk nadal zależały zatem przede wszystkim od dobrej woli Moskwy.

W latach 1991-1992 na ogół niekorzystnie układały się stosunki z sąsiednią Polską. Zaciążyły przede wszystkim historyczne litewskie resentymenty odwołujące się do wydarzeń $\mathrm{z}$ dwudziestolecia międzywojennego. Ale z litewskiej perspektywy niepokojącą przesłanką była również próba ustanowienia autonomii narodowo-terytorialnej, podjęta wcześniej przez przedstawicieli polskiej mniejszości na Wileńszczyźnie. Mimo że polskie władze oficjalnie odcinały się od autonomistów, to jednak domagały się zaprzestania przez litewski rząd działań interpretowanych jako szykanowanie polskiej mniejszości (chodziło m.in. o likwidację ustanowionego w 1991 r. zarządu komisarycznego w zamieszkanych przez polską ludność rejonach i rozpisanie wyborów samorządowych). Stanowisko Warszawy było przez Litwinów interpretowane jako ingerencja i próba podważenia integralności ich państwa. W efekcie nie tylko wśród rządzących, ale także w wielu kręgach społecznych wyraźnie odczuwalny stał się niepokój dotyczący dalszych losów Wileńszczyzny. Zupełnie poważnie obawiano się, że współczesna Polska może domagać się zwrotu tego regionu, który przed wybuchem II wojny światowej stanowił część ówczesnej Rzeczypospolitej. Reakcją było usztywnianie stanowiska wobec kolejnych polskich propozycji kompromisowych uregulowań wzajemnych relacji. Zwłaszcza wywodząca się z Sajudisu prawica zaczęła traktować nieprzejednane stanowisko wobec Polski oraz polskiej mniejszości na Litwie w kategoriach narodowych imponderabiliów ${ }^{3}$.

Sajudis nigdy nie stanowił monolitu, a raczej szeroką koalicję wielu różnorodnych sił społecznych i politycznych. Kiedy strategiczny cel w postaci odbudowy

1 V. Kašauskienè, Lietuvos Respublikos vyriausybès. Ju kaita ir veiklos bruožai 1990-2007, Vilnius 2007, s. 245-246.

2 G. Surgailis, Rusijos kariuomenès išvedimas 1990-1993, Vilnius 2005, s. 55-68.

3 Szerzej o uwarunkowaniach litewskiej polityki wobec tej mniejszości w latach rządów Sajudisu zob. V. Sirutavičius, Lietuviai ir lietuvos Lenkai, Lietuva ir Lenkija 1988-1994 metais, Vilnius 2017, s. 229-280; w polskiej literaturze wydarzenia na Wileńszczyźnie w latach 1989-1991 obszernie przedstawiła m.in. B. Jundo-Kaliszewska, Zakładnicy historii. Mniejszość polska w postradzieckiej Litwie, Łódź 2019, s. 123-272; zob. też: M. Stefanowicz, Polityka etniczna Litwy w latach 1990-2004, Kraków 2019, s. 68-74. Na temat polskiej polityki wobec Litwy na przełomie lat osiemdziesiątych i dziewięćdziesiątych XX w. zob. K. Sidorkiewicz, Od trudnego sąsiedztwa po strategiczne partnerstwo. Polska wobec Litwy w latach 1990-2004, Elbląg 2014, s. 19-53. 
niepodległego państwa został osiągnięty, nastąpił proces dekompozycji ruchu. Konflikty, dotychczas tłumione, wybuchły teraz ze zdwojoną siłą. Rodziły się kolejne partie polityczne. Liderzy zaangażowali się w zażarte spory ideologiczne i personalne. W 1992 r. coraz bardziej słabła pozycja Landsbergisa, oskarżanego o arogancję i dyktatorskie zapędy. Jednocześnie w Radzie Najwyższej trwały prace nad nową konstytucją. W ogniu litewskiej „wojny na górze” nie udało się zwolennikom byłego lidera Sajudisu przeforsować propozycji znacznego rozszerzenia uprawnień głowy państwa. Wynik rozpisanego w tej sprawie referendum okazał się niewiążący ${ }^{4}$, co interpretowano jako osobistą porażkę Landsbergisa. Licząc jeszcze na mobilizację elektoratu, prawe skrzydło Sajudisu w Radzie Najwyższej w warunkach bardzo ostrego konfliktu politycznego doprowadziło do skrócenia kadencji parlamentu i rozpisania przyspieszonych wyborów.

\section{Od wyborów parlamentarnych do wyborów prezydenckich}

Jesienne wybory w 1992 r. były poprzedzone agresywną kampanią, w której koalicja Sajudisu oraz większość partii politycznych chętnie posługiwały się antysowiecką i nacjonalistyczną retoryką. Mimo że przedwyborcze sondaże nie przewidywały zwycięstwa LDPP, ugrupowanie to było silnie atakowane za postkomunistyczny rodowód. Stronnictwo Brazauskasa oparło kampanię na eksponowaniu negatywnych kosztów reform, obiecując powrót do sprawdzonych rozwiązań. Brazauskas osobiście jeździł do rozpadających się kołchozów, pochylał się nad ludzkimi problemami, obiecując „naprawienie błędów” i odsunięcie od władzy nieudaczników. Podkreślał także konieczność „większego pragmatyzmu” w stosunkach z Rosją, ponieważ Litwa ciągle jeszcze była niesamodzielna gospodarczo. Jakby na zamówienie tuż przed wyborami kolejny raz wstrzymano dostawy rosyjskiej ropy naftowej i gazu, co jeszcze wzmacniało argumenty lidera LDPP (niektórzy komentatorzy spekulowali nawet, że w taki sposób Moskwa wsparła litewskich postkomunistów) ${ }^{5}$. Wyniki wyborów przeprowadzonych w dwóch turach na przełomie października i listopada 1992 r. były ogromnym zaskoczeniem nie tylko dla mieszkańców Litwy. Postkomuniści z LDPP zdobyli bezwzględną większość, obsadzając aż 73 miejsca w 141-osobowym parlamencie ${ }^{6}$. Dotkliwej porażki doznały ugrupowania prawicowe i centrowe (niektóre stacjonujące samodzielnie nie przekroczyły progu wyborczego). Stało się tak przede wszystkim z powodu utożsamienia negatywnych skutków kryzysu ekonomicznego i politycznego z rządami Sajudisu. Większość

${ }^{4}$ W referendum zorganizowanym 23 maja 1992 r. liczba głosów „za” nie przekroczyła wymaganych $51 \%$ spośród uprawnionych.

5 Sutartys su Rusija pasirešytos, gal greit bus ir naftos, „Lietuvos Rytas” (13 X 1992).

${ }^{6}$ Sajudis musiał zadowolić się jedynie 30 mandatami w Sejmie, Litewska Partia Chrześcijańskich Demokratów obsadziła 18 miejsc, umiarkowana Litewska Partia Socjaldemokratyczna - 8, Związek Narodowców - 4, liberalny Litewski Ruch Centrum - 2, Związek Polaków - 4. 
litewskiego społeczeństwa dobitnie opowiedziała się za socjalnym bezpieczeństwem, ale także odrzuciła styl uprawiania polityki przez partie, które w ostatnim czasie określały swą tożsamość głównie za pomocą haseł antykomunistycznych i narodowo-patriotycznych ${ }^{7}$. Równolegle do pierwszej tury wyborów parlamentarnych mieszkańcy Litwy zaakceptowali w referendum projekt nowej konstytucji. Między innymi przywracała ona historyczną nazwę parlamentu - Sejm (Seimas) i posłów oraz urząd prezydenta wybieranego w wyborach powszechnych ${ }^{8}$.

Ugrupowanie Brazauskasa było zaskoczone rozmiarem własnego sukcesu. Z kolei w państwach Zachodu wynik litewskich wyborów wywołał zaniepokojenie perspektywą nawrotu komunizmu. W Wilnie krążyły pogłoski, wedle których Sajudis zamierzał wezwać do oporu przeciw spodziewanej decyzji o integracji kraju ze Wspólnotą Niepodległych Państw. Postkomuniści byli także oskarżani o chęć zatrzymania ewakuacji rosyjskiego wojska. Rozwiewając wątpliwości, przewodniczący LDPP natychmiast zapewnił, że nowa większość parlamentarna nie zamierza dokonywać żadnego zamachu na suwerenność ojczyzny. Deklarując nawet ogólne wsparcie dla kierunku rozpoczętych reform (chociaż nie dla sposobu ich wdrażania), zwrócił się do wszystkich pozostałych sił politycznych o stworzenie wielkiej koalicji rządowej. Opinia publiczna z napięciem oczekiwała zwłaszcza na reakcję Landsbergisa. Ten jednak oficjalnie uznał porażkę i pogratulował zwycięzcom. Zapowiedział również, że koalicja $\mathrm{z}$ lewicą postkomunistyczną nie jest możliwa, dlatego jego ugrupowanie przejdzie do opozycji parlamentarnej. Podobne stanowisko zajęli liderzy innych partii centroprawicowych.

Już podczas pierwszego posiedzenia Sejmu 25 listopada 1992 r. okazało się, że wbrew powyborczym deklaracjom LDPP nie zamierza dzielić się władzą. Głosami lewicowej większości wybrano Brazauskasa na przewodniczącego parlamentu. Wbrew gorącym protestom opozycji, która spodziewała się oddania jej funkcji wiceprzewodniczącego, został nim również polityk LDPP, Česlovas Juršènas.

\footnotetext{
${ }^{7}$ Litwa była pierwszym państwem w środkowo-wschodniej Europie, w którym po upadku ZSRR do władzy po zwycięstwie w wolnych wyborach powróciło ugrupowanie wywodzące się z dawnej partii komunistycznej. Kiedy w kolejnych latach również $\mathrm{w}$ innych państwach regionu (m.in. w 1993 r. w Polsce) tryumfowali postkomuniści, niektórzy publicyści, doszukując się analogii, zaczęli mówić nawet o „litewski syndromie”. Zob. np.: G. Gromadzki, Litewski syndrom, „Gazeta Wyborcza" (3 III 1996).

${ }^{8}$ Lietuvos Respublikos Konstitucija, http://www3.lrs.lt/home/Konstitucija/Konstitucija.htm\#NESIJUNGIMO (dostęp: 30.08.2020). Stosunkowo rozległe prerogatywy głowy państwa skłaniają badaczy do określenia ustroju Litwy mianem semiprezydenckiego. Zob. A. Lukošaitis, Prezidentas Lietuvos politinèje sistemoje: vietos ir galio paieškos, „Politologija” (1998), nr 2, s. 38-53; V. Pugačiauskas, Lithuania's semi-Presidential Model: Prospects For The Stability of The Inter-Institutional Relations, „Lithuanian Political Science Yearbook” (2002, Vilnius 2003), s. 11-21; W. Kręcisz, Republika Litewska, w: Ustroje państw współczesnych, t. 2, red. E. Gdulewicz, Lublin 2002, s. 102-134; J. Zieliński, Prezydent Republiki Litewskiej, w: Prezydent w państwach współczesnych, red. J. Osiński, Warszawa 2009, s. 357-400; T. Godlewski, Udział prezydenta Republiki Litewskiej w ustawodawstwie, „Przegląd Prawa Konstytucyjnego” (2014), nr 3, s. 23-36.
} 
Cel tego manewru stał się jasny, gdy wkrótce przegłosowano uchwałę o tymczasowym powierzeniu obowiązków prezydenta państwa przewodniczącemu, którego w okresie przejściowym miał zastąpić oczywiście wiceprzewodniczący Sejmu? ${ }^{9}$. Oburzonym posłom opozycji pozostały protesty.

Ugrupowanie Brazauskasa obejmowało rządy pod hasłami radykalnej zmiany przede wszystkim dotychczasowej polityki społecznej, ekonomicznej i zagranicznej. Jednak przejmując władzę w drodze wolnych wyborów, LDPP musiała liczyć się nie tylko z nastrojami mieszkańców i stanowiskiem Moskwy, ciągle trzymającej Litwę w ekonomicznym szachu. Opuszczając ZSRR, Litwa zadeklarowała chęć przynależności do demokratycznego świata. Na Zachodzie litewscy postkomuniści nie cieszyli się uznaniem, a za gwaranta kontynuacji przemian uchodził Landsbergis. Należało zatem dowieść reformatorskiego nastawienia. Ponadto zgodnie z konstytucją Litwę czekały niebawem wybory prezydenckie. Co prawda na przełomie 1992 i 1993 r. kandydatura lidera LDPP biła rekordy popularności w sondażach, ale ostateczny wynik nie był przesądzony. Sytuacja wymagała zatem rozwiązań przejściowych, które uwiarygodniłyby nową władzę nie tylko w oczach własnych obywateli, ale także opinii międzynarodowej. W tym kontekście kluczowy był skład nowego rządu, a szczególnie nominacja jego szefa. Ku zaskoczeniu działaczy LDPP Brazauskas zaproponował na to stanowisko Bronislovasa Lubysa, dotychczasowego wicepremiera w gabinecie firmowanym jeszcze przez Sajudis. Lubys był inżynierem chemikiem, z bogatym doświadczeniem w zarządzaniu przedsiębiorstwami państwowymi i cenionym dorobkiem naukowym, a także jednym z prekursorów prywatnego biznesu na Litwie. Uchodził przede wszystkim za technokratę, sympatyzującego z rodzącym się ruchem liberałów ${ }^{10}$. W rządzie, powołanym w grudniu 1992 r., zasiadło tylko trzech ministrów z LDPP. Szefowie czterech resortów zachowali stanowiska zajmowane w poprzednim gabinecie. Dobór ministrów sugerował, że zapowiedź korekty polityki państwa, głośno powtarzana jeszcze podczas kampanii, $\mathrm{w}$ istocie nie zwiastowała rewolucji. Priorytetem było opanowanie trudnej sytuacji gospodarczej, a nie rozliczenie ekipy Sajudisu. Odgrywając główną, choć zakulisową rolę w powstawaniu rządu, Brazauskas przygotował grunt pod kolejną wyborczą wygraną. Wbrew stanowisku opozycji, która nalegała na odłożenie wyborów prezydenckich, Sejm wyznaczył ich termin już na połowę lutego $1993 \mathrm{r}$.

9 Lietuvos Respublikos Seimo Stenogramos, posiedzenie 1, 25 XI 1992, https://e-seimas.lrs.lt/portal/ legalAct/lt/TAK/TAIS.235315 (dostęp: 31.08.2020); Pirmasis Seimo posédis: iškilmiu daina su ateitis ir praeitis priedainiais, „Lietuvos Rytas” (26 XI 1992).

10 Podobnie jak wielu członków KPL, Lubys w latach 1988-1990 był politycznie zaangażowany po stronie reformatorskiego skrzydła partii. W 1990 r. został wybrany do Rady Najwyższej LSRR z poparciem Sajudisu, znalazł się wśród sygnatariuszy Aktu Przywrócenia Państwa Litewskiego. W wyborach 1992 r. nie kandydował, zamierzając wycofać się z życia politycznego. Objął funkcję premiera, ulegając prośbie Brazauskasa. Szerzej zob. R. Pukenė, Neįtikètina Bronislovo Lubio gyvenimo istorija: draugai, turtai, klaidos ir testamento paslaptis, https://www.delfi.lt/multime$\mathrm{dija} / \mathrm{k} 11 /$ neitiketina-bronislovo-lubio-gyvenimo-istorija-draugai-turtai-klaidos-ir-testamentopaslaptis.d?id=83415867 (dostęp: 2.11 .2020$)$. 
Po porażce w wyborach do Sejmu w koalicji Sajudisu zapanowała grobowa atmosfera. Podniosły się głosy kwestionujące przywództwo Landsbergisa. Niektórzy działacze zainicjowali nawet rozmowy ze Stasysem Lozoraitisem, zasłużonym działaczem emigracyjnym i dyplomatą, namawiając go do udziału w wyborach prezydenckich i oferując poparcie ${ }^{11}$. Część kierownictwa ruchu otwarcie zaangażowała się w prace nad tworzeniem nowych projektów politycznych. Rozpad Sajudisu w jego dotychczasowej formule wydawał się przesądzony. Na początku stycznia $1993 \mathrm{r}$. Landsbergis świadom nieuchronnej porażki ogłosił, że w obecnej sytuacji rezygnuje z ubiegania się prezydenturę. Wezwał również swoich zwolenników do głosowania na Lozoraitisa ${ }^{12}$. Zamiar startu w wyborach zgłaszało wcześniej kilkoro kandydatów, ale ostatecznie wymaganą ordynacją liczbę podpisów, oprócz Brazauskasa, zebrał jedynie Lozoraitis. Paradoksalnie poparcie ze strony sajudisowskiej prawicy było w określonych warunkach wręcz obciążeniem wizerunkowym. Lozoraitis chciał być postrzegany jako polityk niezależny, pragnął budować realną alternatywę dla lewicy postkomunistycznej. Jego kandydatura została oficjalnie zgłoszona przez Ruch Centrum (niebawem przekształcony w partię pod nazwą Litewski Związek Centrum), założony przez Romualdasa Ozolasa, dawniej jednego z liderów Sajudisu, obecnie lokującego się w opozycji do Landsbergisa ${ }^{13}$. Lozoraitisowi udało się pozyskać poparcie niemal wszystkich ugrupowań opozycyjnych, znajdujących się w defensywie po przegranych wyborach parlamentarnych. Polityczną wiarygodność zdobywał nie tylko prowadzoną $\mathrm{w}$ amerykańskim stylu kampanią, nazwiskiem i wcześniejszymi zasługami, ale także apelami o narodową zgodę i kooperację. Jednocześnie przestrzegał, że zwycięstwo Brazauskasa doprowadzi do niebezpiecznego zdominowania sceny politycznej przez jedną partię, co zaszkodzi młodej demokracji.

Z kolei Brazauskas wytykał kontrkandydatowi, że przebywając za granicą, nie uczestniczył w wydarzeniach przełomowych dla najnowszej historii kraju, zatem nie zna bieżących problemów społecznych i gospodarczych. Przedstawiał Lozoraitisa wręcz jako bujającego w obłokach intelektualistę, marionetkę w rękach Landsbergisa. W kampanii akcentowano, że wygrana Brazauskasa, specjalisty od gospodarki, twardo stąpającego po ziemi i świetnie orientującego się w miejscowych realiach, zagwarantuje Litwinom nie tylko upragniony dobrobyt, ale też polityczną stabilizację $^{14}$. Wybory odbyły się 14 lutego 1993 r. Przy frekwencji wynoszącej

11 W. Adamkus, Alma i Valdas. Nasz los - Litwa, Toruń 2008, s. 176. Stasys Lozoraitis jr (ur. w 1924 r.) był synem ministra spraw zagranicznych niepodległej Litwy w latach międzywojennych. Po 1940 wraz z ojcem opuścił Litwę. Od 1943 pracował w przedstawicielstwie Litwy w Watykanie. Działał w litewskich organizacjach emigracyjnych. W 1991 na prośbę działaczy Sajudisu zgodził się objąć urząd ambasadora Republiki Litewskiej w Stanach Zjednoczonych. Późniejszy prezydent Valdas Adamkus, przyjaciel Lozoraitisa, był jednym z szefów jego kampanii wyborczej w $1993 \mathrm{r}$.

${ }^{12}$ K. Janiškis, Prezidento rinkimu išvakarèse ir žigsniai atgal gali būti naudingi ateičiai?, „Lietuvos Rytas" (5 I 1993).

13 R. Ozolas, Lietuva 1990-1993 metais. Istorija karštomis pédomis, Vilnius 2008, s. 252.

${ }^{14}$ Iš A. Brazausko, kandidato ì Lietuvos Respublikos Prezidentus, programos, „Respublika” (28 I 1993); R. Sakalauskaitè, Algirdas Brazauskas: dabartinès politinés audros ramus miego nerumsčia, 
$78,6 \%$ na Brazauskasa oddano 60,03\%, Lozoraitisa zaś 38,28\% głosów ${ }^{15}$. Pod koniec lutego Brazauskas złożył uroczystą przysięgę i oficjalnie objął urząd.

\section{Pierwsze miesiące prezydenta Algirdasa Brazauskasa - litewskie znaki zapytania}

Natychmiast po wygranej nowy prezydent zgodnie $\mathrm{z}$ wymogami konstytucji zrezygnował z członkostwa w rządzącej partii, chociaż w praktyce nadal miał w niej decydujące zdanie. Zaprezentował także ekipę współpracowników, przeważnie wywodzących się - jak on sam - ze skrzydła dawnej KPL, które ostatecznie opowiedziało się za niepodległością. Najbliższym doradcą, nieoficjalnie nazywanym wiceprezydentem, został Rajmundas Rajeckas, ceniony ekonomista z dużym dorobkiem naukowym (w latach 1988-1990 członek tzw. Sejmu Sajudisu). Według zapisów konstytucyjnych zaraz po wyborach prezydenckich gabinet Lubysa musiał podać się do dymisji. Międzywyborczy okres przejściowy dobiegł końca, dlatego Brazauskas uznał, że czas na zmiany w rządzie, nad którym chciał sprawować większą kontrolę. Stanowisko premiera otrzymał (10 marca) Adolfas Šleževičius, wcześniej namaszczony także na przewodniczącego LDPP. Prezydent zachwalał w Sejmie nowego szefa rządu jako młodego i rzutkiego specjalistę od gospodarki, $\mathrm{z}$ doświadczeniem $\mathrm{w}$ prywatnym biznesie. Jego gabinet miał już bardziej partyjny charakter, chociaż dwóch ministrów (transportu i obrony) zasiadało w kolejnych rządach nieprzerwanie od $1990 \mathrm{r}$. Brazauskas naciskał na utrzymanie stanowiska zwłaszcza przez ministra obrony Audriusa Butkevičiusa, odpowiedzialnego za budowę sił zbrojnych i nadzorującego proces ewakuacji rosyjskich wojsk z Litwy. W szeregach LDPP dały się słyszeć głosy niezadowolenia z powodu tej decyzji. Prezydent uznał jednak, że w newralgicznych kwestiach obronności i bezpieczeństwa korzystniejsze dla kraju będzie zachowanie ciągłości decyzyjnej ${ }^{16}$.

Natomiast zadanie Šleževičiusa stanowiło podjęcie natychmiastowych starań o poprawę sytuacji gospodarczej. Tuż po przejęciu obowiązków szef rządu udał się do Sztokholmu na konferencję ekonomiczną, usiłując pozyskać wsparcie międzynarodowych instytucji finansowych. Premier wykorzystał również szansę na korzystne zaprezentowanie nowej ekipy, dotychczas postrzeganej przede wszystkim

\footnotetext{
„Lietuvos Rytas” (11 II 1993); A. Žuko klausimai išrinktam LR Prezidentui A. Brazauskui, „Respublika" (17 II 1993).

15 W polskiej literaturze uwarunkowania kampanii parlamentarnej 1992 i prezydenckiej 1993 r. na Litwie stosunkowo najszerzej zostały opisane w pracy: J. Sobczak, Studia nad wyborami prezydenckimi i parlamentarnymi na Litwie i Białorusi, Poznań 1997, s. 7-74.

16 V. Kašauskienè, op. cit., s. 207. Adolfas Šleževičius (ur. 1948), inżynier i ekonomista, od końca lat siedemdziesiątych był etatowym pracownikiem aparatu KPL. Od 1991 kierował litewsko-norweskim przedsiębiorstwem zajmującym się obrotem produktami rolnymi. Na temat doradców prezydenta Brazauskasa zob. S. Grybkauskas, M. Tamošaitis, Žmogus, jungęs epochas. Algirdo Brazausko politine biografija, Vilnius 2019, s. 273-274.
} 
jako spadkobiercy systemu komunistycznego. W zamian za zobowiązanie do bardziej rygorystycznej kontroli wydatków publicznych i kontynuowania reform Unia Europejska zaoferowała wówczas Litwie partycypację w funduszach pomocowych. Wkrótce podpisano również umowę handlową. Wilno rozpoczęło także zabiegi o zawarcie umowy stowarzyszeniowej. W maju $1993 \mathrm{r}$. Litwa została przyjęta do Rady Europy. W grudniu tego roku Parlament Europejski zaaprobował program szerokiej współpracy z Wilnem, przygotowany przez Brukselę ${ }^{17}$.

Zgodnie z zapowiedziami z kampanii wyborczych szansy na ożywienie gospodarcze szukano także w intensyfikacji kontaktów z dawnymi republikami radzieckimi, zwłaszcza Białorusią i Ukrainą. Zdaniem polityków lewicy poprzednie rządy, kierując się głównie względami ideologicznymi, doprowadziły na tym polu do karygodnych zaniedbań. Już w połowie marca 1993 r. do Wilna przybył białoruski premier Wiaczesław Kiebicz. Podpisano wówczas umowę o wolnym handlu. Było to pierwsze tego typu porozumienie zawarte przez Litwę z państwem należącym niegdyś do ZSRR $^{18}$. W lipcu i sierpniu 1993 r. doszło także do szeregu spotkań z przywódcami ukraińskimi (m.in. prezydentem Leonidem Krawczukiem i premierem Leonidem Kuczmą). Również w tym wypadku owocem było aż siedem umów o współpracy gospodarczej i tranzycie ${ }^{19}$. Ponadto jesienią prezydent Brazauskas odwiedził kilka dawnych radzieckich republik środkowoazjatyckich, m.in. Kazachstan, a także Chiny. Z podróży również przywiózł pakiet porozumień gospodarczych ${ }^{20}$.

W kontekście starań podjętych przez lewicę w celu ratowania gospodarki niemal symboliczne znaczenie miało sfinalizowanie starań o przywrócenie narodowej waluty - lita (litas). Zabiegi o zastąpienie radzieckiego rubla rozpoczęto jeszcze w 1990 r., nie sprzyjała im jednak niestabilna sytuacja polityczna i ekonomiczna oraz brak rezerw finansowych. Rządom firmowanym przez Sajudis ogromnym wysiłkiem udało się utworzyć minimalny fundusz stabilizacyjny oraz wprowadzić do obiegu walutę przejściową (tzw. talony), a także zamówić druk banknotów za granicą. Prasa ujawniła, że przy okazji doszło jednak do serii spektakularnych i bardzo kosztownych dla państwa nadużyć. W marcu 1993 r. kierownictwo banku centralnego zostało oskarżone o spowodowanie opóźnień i na wniosek prezydenta odwołane przez Sejm. Akcji towarzyszyła szeroka kampania medialna ${ }^{21}$.

17 R. Martikonis, Penkeri Lietuvos ir Europos Sajungos santykiu metai, „Politologija” (1996), nr 8, s. 141-149.

18 Pasirašyti Lietuvos ir Baltorusijos susitarimai, „Respublika” (17 III 1992); E. Bukinas, Pavasaris Baltarusijos premjero vizitas ị Lietuvą apti role dvišaliu santykių ledus, „Lietuvos Rytas” (17 III 1993).

19 Lietuvos Respublikos Vyriausybes ir Ukrainos Vyriausybes susitarimas „Dèl bendradarbiavimo principu ir tarpusavio santykiu salygu transporto srityje”, 7 VII 1993, https://e-seimas.lrs.lt/portal/ legalAct/lt/TAD/TAIS.11215 (dostęp: 8.09.2020); R. Sakalauskaité, Lietuva ir Ukraina: dvieju šaliu interesu erdve - nuo Baltijos iki Juodosios jūros, „Lietuvos Rytas” (8 VII 1993).

20 Algirdo Brazausko vizitai i Rytus, „Lietuvos Rytas” (6 XI 1993).

${ }^{21}$ Szerzej zob. B. Vainauskienè, Skandalingoji lito istorija, Vilnius 2003, s. 136 i n.; D. Jablonskaite, Lito dvidešimtmetis - su mirties ženklu, http://www.15min.lt/naujiena/aktualu/istorija/lito-dvidesimtmetis-su-mirties-zenklu-582-347247 (dostęp: 4.09.2020). 
Ostateczny sukces w postaci wprowadzenia lita (25 czerwca 1993 r.) został przez opinię publiczną przypisany lewicowej władzy. Podobnie jak stopniowe ustabilizowanie sytuacji gospodarczej i zahamowanie inflacji, co nastąpiło w pierwszych latach działalności gabinetu Šleževičiusa.

Zwycięstwa postkomunistów w wyborach parlamentarnych i prezydenckich były szokiem dla koalicji Sajudisu. Konieczność przejścia do opozycji przyspieszyła ewolucję ruchu, a w rezultacie także narodziny kolejnych sił politycznych odwołujących się do patriotyczno-niepodległościowego etosu. Na początku maja $1993 \mathrm{r}$. prawe skrzydło Sajudisu utworzyło ugrupowanie pod nazwą Związek Ojczyzny (Litewscy Konserwatyści), lit. Tèvynès Sąunga (Lietuvos konservatoriai). Na jego czele stanął Landsbergis. Partia przejęła większość mandatów Sajudisu w Sejmie i stała się odtąd główną siłą opozycyjną.

Parlamentarne forum dawało konserwatystom i pozostałym partiom centroprawicy całkiem szerokie pole aktywności. Co prawda dysponując wspólnie zaledwie ponad 50 mandatami, nie mogli liczyć na przejęcie władzy. W grę wchodziło wszakże nie tylko krytyczne recenzowanie, ale w niektórych przypadkach skuteczne blokowanie rządu i prezydenta. Niedawno przyjęta konstytucja zawierała zapisy sprawdzone w systemach demokratycznych. W zakresie kultury politycznej nadal jednak chętnie praktykowano rozwiązania odziedziczone głównie po realiach ZSRR. Wielu obecnych sejmowych posłów, wzorem radzieckich deputowanych, utożsamiało władzę ustawodawczą i wykonawczą. Przekonanie o wszechwładzy Rady Najwyższej umocniło się jeszcze w niedawno zakończonym okresie zmagań o niepodległość. Deputowani często uznawali wówczas, że wyborczy mandat obliguje ich do odgrywania roli superrządu. Odpowiednie komisje Rady niejednokrotnie uznawały się za uprawnione do inicjowania i kształtowania polityki państwa niemal w każdym zakresie, a także korygowania decyzji innych organów. W przekonaniu deputowanych bieżące zapotrzebowanie uzasadnione wyższą koniecznością uprawniało ich nawet do forsowania doraźnych zmian o charakterze konstytucyjnym $^{22}$. Podobne wzorce w naturalny sposób przenoszono teraz do Sejmu. Kiedy ugrupowania centroprawicowe oswoiły się już z rolą opozycji, nawiązały ściślejszą współpracę na gruncie kontestowania poczynań władzy. Płaszczyzną konfrontacji była m.in. polityka zagraniczna. Poważnie obawiano się, że postkomunistyczna LDPP będzie chciała na tym polu dokonać radykalnej zmiany, co mogło doprowadzić nawet do utraty z trudem wywalczonej niepodległości. Opozycja uznawała

22 Litewski badacz Evaldas Nekrašas porównał litewską Radę Najwyższą (i pierwszy okres funkcjonowania demokratycznego Sejmu) do Konwentu z czasów rewolucji francuskiej. Zob. E. Nekrašas, Lithuanian Political System and Foreign Policy Decision Making, „Lithuanian Foreign Policy Review” (1999), nr 4, http://www.lfpr.lt/uploads/File/1999-4/Nekrasas.pdf (dostęp: 3.04.2016); idem, Legislature and the Executive in Foreign Policy Making, Vilnius 1994, s. 10-12. Interesująca analiza stanu kultury politycznej na Litwie w okresie transformacji por. V. Vardys, Lietuvos politine kultūra ir laiko reikalavimai, http://www.partizanai.org/i-laisve-1993-116-153/3072-lietuvos-politine-kultura-ir-laiko-reikalavimai (dostęp: 11.09.2020). 
się za moralnie uprawnioną do pilnowania dotychczasowego kursu. W sejmowej komisji spraw zagranicznych, idealnie nadającej się do tego zadania, zasiadła silna reprezentacja opozycji z Landsbergisem, Emanuelisem Zingerisem, Algirdasem Saudargasem i Kazysem Bobelisem ${ }^{23}$.

Ustawa zasadnicza dawała prezydentowi stosunkowo szerokie, chociaż ogólnie określone, uprawnienia $\mathrm{w}$ zakresie polityki zagranicznej. Wszelako zwłaszcza w kontaktach z Zachodem Brazauskas początkowo nie czuł się zbyt pewnie. Obciążenie stanowiły przeszłość komunistycznego sekretarza oraz słaba znajomość języków obcych, brak kontaktów międzynarodowych i doświadczenia ${ }^{24}$. Za to były prezydent uważał się za eksperta do spraw rzeczywistości poradzieckiej. Jeszcze przed wyborami Brazauskas deklarował co prawda ogólne poparcie dla prozachodniego kierunku rozwoju kraju, jednakże w kampanii i pierwszych miesiącach po elekcji często wyrażał opinię o tym, że Litwa powinna przede wszystkim wykorzystać atut położenia geograficznego i odegrać rolę „pomostu” między światem zachodnim a poradzieckim Wschodem i pozostać państwem neutralnym $^{25}$. Podobnie szef dyplomacji z ramienia LDPP, Povilas Gylys, krytycznie oceniał politykę zagraniczną Sajudisu, którą nazywał romantyczną i niedojrzałą. Poprzednikom zarzucał uleganie ideologicznemu zacietrzewieniu. Pojawiające się na prawicy marzenia o członkostwie Litwy w NATO i Unii Europejskiej nazywał mrzonkami niepotrzebnie antagonizującymi Rosję ${ }^{26}$. Członkowie sejmowej komisji spraw zagranicznych oraz posłowie opozycji ostro reagowali na tego typu wypowiedzi, zarzucając władzom zdradę narodowych interesów: dążenie do rezygnacji ze starań do integracji z Zachodem na rzecz zacieśnienia związków z posowiecką

${ }^{23}$ Emanuelis Zingeris - jeden z czołowych działaczy Sajudisu, przewodniczący komisji spraw zagranicznych Rady Najwyższej (1990-1992); Algirdas Saudargas - lider Litewskiej Partii Chrześcijańskich Demokratów, w latach 1990-1992 minister spraw zagranicznych; Kazys Bobelis - emigracyjny działacz polityczny cieszący się dużym autorytetem, po powrocie na Litwę w $1991 \mathrm{r}$. lider Związku Chrześcijańskich Demokratów.

${ }^{24} \mathrm{~W}$ kancelarii prezydenta głównym doradcą do spraw polityki międzynarodowej został Justis Paleckis, dziennikarz, były działacz partii komunistycznej i długoletni pracownik radzieckiej dyplomacji (w strukturach MSZ LSRR).

25 Swoje poglądy na ten temat Brazauskas najpełniej sformułował w maju 1993 r. podczas wykładu dla zagranicznych dyplomatów akredytowanych na Litwie. Zob. A. Brazauskas, Penkeri Prezidento metai, Vilnius 2000, s. 213-219. Jednak zdaniem niektórych badaczy zaprezentowana wówczas koncepcja neutralności mogła być zabiegiem taktycznym. Na terytorium kraju nadal stacjonowało bowiem wojsko byłego ZSRR, co Moskwa chętnie wykorzystywała jako środek nacisku na Wilno. Kreml nie ukrywał niechętnego stanowiska wobec prozachodniego nastawienia byłej pribałtyki. Wiosną i latem 1993 r. zabiegi o wycofanie obcych wojsk stanowiły absolutny priorytet dyplomacji litewskiej, ale sukces nie był jeszcze przesądzony. W takich okolicznościach bardziej zrozumiała mogła być ostrożność Brazauskasa w deklarowaniu wyboru przyszłej międzynarodowej orientacji Litwy. E. Nekrašas, Kritiniai pamąstai apie Lietuvos užsienio politiką, „Politologija” (2009), nr 2, s. 125; K. Paulauskas, Kieno saugumas? Kuri tapatybè? Kritinès saugumo studijos ir Lietuvos užsienio politika, Vilnius 2010, s. 121.

${ }^{26}$ Lietuvos užsienio politika: romantikai užleidžia vieta pragmatikams? (rozmowa z P. Gylysem), „Lietuvos Rytas” (28 I 1993). 
Wspólnotą Niepodległych Państw. Prezydenta i rząd stale oskarżano o prowadzenie tajnej dyplomacji i karygodne ustępstwa na niekorzyść kraju. Twierdzono, że dobitnym wyrazem niepokojących tendencji było inspirowane przez Brazauskasa w maju 1993 r. odwołanie Lozoraitisa z funkcji ambasadora w USA. Opozycja roztaczała przed społeczeństwem apokaliptyczną wizję powrotu Litwy do stanu zależności od Moskwy. W celu wywarcia nacisku na obóz rządzący nie wahano się wykorzystywać wpływów w mediach ${ }^{27}$.

Jednym z postulatów lewicy przed wyborami parlamentarnymi było uregulowanie stosunków z Polską. Utrzymywanie dotychczasowego stanu uznawano za niekorzystne dla kraju, zwłaszcza z powodów ekonomicznych, ale też ze względu na negatywny oddźwięk międzynarodowy. Na początku stycznia 1993 r. premier Lubys swą pierwszą zagraniczną wizytę złożył w Polsce. Ówczesne ustalenia dotyczyły głównie zintensyfikowania współpracy gospodarczej, na czym szczególnie zależało stronie litewskiej. Lubys dał do zrozumienia, że jego rząd pragnie zajmować się budowaniem przyszłości, dlatego gotów będzie przejść do porządku nad nieporozumieniami dotyczącymi oceny historii ${ }^{28}$. Polskie władze stale wyrażały zainteresowanie jak najszybszym uregulowaniem stosunków z Litwą i zawarciem traktatu międzypaństwowego. Biorąc za dobrą monetę publiczne deklaracje litewskiego premiera, Warszawa już w lutym przekazała do Wilna projekt stosownej umowy. Trwająca akurat na Litwie kampania prezydencka oraz zmiana rządu spowodowały, że prace nad traktatem rozpoczęly się z pewnym opóźnieniem. W komisji spraw zagranicznych Sejmu prawica bardzo zdecydowanie sprzeciwiła się zawarciu umowy, która nie będzie uwzględniała litewskiej interpretacji wydarzeń historycznych. Stanowczo domagano się od strony polskiej przede wszystkim potępienia zajęcia Wilna przez gen. Lucjana Żeligowskiego w 1920 r. oraz przyznania, że w latach międzywojennych Wileńszczyzna znajdowała się pod okupacją polską. Lewicowy rząd i prezydent zostali oskarżeni o zamiar rezygnacji z tych postulatów, napiętnowani za planowanie narodowej zdrady i spiskowanie przeciw ojczyźnie.

Relacje z Polską tradycyjnie obfitowały w tożsamościowy kontekst i czytelne symbole nacjonalistyczne. Wchodzenie na tym polu $\mathrm{w}$ konfrontację $\mathrm{z}$ prawicą było dla LDPP i Brazauskasa ryzykowne moralnie i wizerunkowo. Przełomowi w stosunkach z Warszawą nie sprzyjało nastawienie opinii publicznej, skutecznie mobilizowanej przez opozycję. Ostro zaatakowane władze postanowiły zatem nie zrywać z dotychczasowym zachowawczym kursem wobec Warszawy, gdyż w atmosferze swego rodzaju patriotycznego szantażu naraziłoby to rządzącą ekipę na zbyt poważne straty wizerunkowe. Poza tym wielu działaczy postkomunistycznej lewicy było podobnie dogłębnie przekonanych, że polska strona powinna zadośćuczynić

27 A. Račas, Prezidento kritikuotas užsienio reikalu ministras atsistadynti neketina, „Lietuvos Rytas” (18 VI 1993); Prezidentas garantavo Krikščioniu demokratu partijos vadovams, kad politika Rusijos atžvilgiu nesikeičia, „Lietuvos Rytas” (2 VII 1993).

${ }^{28}$ E. Bukinas, Buvusio vienuolyno skiautai kaimyniniu šaulių premjerus paskatino galvoti apie ateiti, o praeiti polikti istorikams, „Lietuvos Rytas” (9 I 1993). 
litewskim krzywdom ${ }^{29}$. Prace nad traktatem zostały zatem wyhamowane. Własny projekt umowy, zawierający passus o potępieniu akcji Żeligowskiego, litewskie Ministerstwo Spraw Zagranicznych przedstawiło Polsce dopiero w czerwcu 1993 r. Następnie rozpoczęły się żmudne negocjacje, w których trakcie strona litewska pozostawała przy swoich postulatach, a polska utrzymywała, że włączenie ocen historii do porozumienia nie jest możliwe przede wszystkim ze względów prawnych. Pertraktacje trwały przez całą drugą połowę roku na zmianę w Wilnie i Warszawie. Litewskie władze wyraźnie nie były gotowe do kompromisu, grały na zwłokę i unikały jasnych zobowiązań ${ }^{30}$. Media na Litwie szczegółowo relacjonowały przebieg rozmów, często odwołując się do historycznych resentymentów. Nastroje społeczne były wyjątkowo silnie stymulowane przez przeciwników porozumienia pojmowanego w dalszym ciągu jako niedopuszczalna kapitulacja i narodowa katastrofa. Mimo zapowiedzi z okresu przedwyborczego lewica nie zdecydowała się także na żadne przyjazne gesty pod adresem polskiej mniejszości, wokół której nadal panował nieprzychylny klimat. Dodatkowo w drugiej połowie $1993 \mathrm{r}$. przez Litwę przetoczyła się kampania wymierzona w polskich weteranów Armii Krajowej (AK) mieszkających na Wileńszczyźnie ${ }^{31}$. Nawiązując do międzywojennej tradycji, zorganizowano nawet specyficzne propagandowe widowisko: „sąd społeczny" nad wileńską AK. Pod presją organizacji nacjonalistycznych rząd powołał specjalną komisję historyków do oceny antylitewskiej działalności polskiego podziemia podczas II wojny światowej. Propagandowa akcja odbijała się negatywnym echem w Polsce. Niewiele zatem wskazywało na możliwość rychłego przełomu w stosunkach między Wilnem a Warszawą.

Latem 1993 r., kiedy na Litwie trwały przygotowania do ostatniego etapu ewakuacji wojsk rosyjskich oraz wizyty papieża Jan Pawła II, doszło do nieoczekiwanego kryzysu wewnętrznego. Na przełomie lipca i sierpnia 1993 r. grupa ok. 140 ochotników z paramilitarnej formacji SKAT (Savanoriškoji krašto apsaugos tarnyba) zbiegła z bronią w ręku do lasu w okolicy Kowna. Przyczyny miały socjalno-kryminalny charakter, ale wkrótce problem nabrał politycznego wydźwięku. Oddziały SKAT zaczęły powstawać $\mathrm{w}$ momencie zagrożenia niepodległości w styczniu 1991 r. i przez pewien okres stanowily namiastkę wojska. Początkowo formacja była poważana i dowartościowana. Jednak utworzenie regularnej armii oraz problemy budżetowe spowodowały narastanie kłopotów organizacyjnych, a nawet

${ }^{29}$ W. Bereś (współpraca J.J. Komar), Okińczyc wileński autorytet. Opowieść o wolnej Litwie, Warszawa 2015, s. 230-231.

30 V. Sirutavičius, Lietuviai ir lietuvos Lenkai..., s. 365-368, 372-374.

31 Według litewskiej interpretacji wileńska AK stanowiła przestępczą organizację bezprawnie działającą w okupowanej Litwie. Twierdzono, że główny cel polskiego podziemia w czasie wojny stanowiło zwalczanie litewskości na Wileńszczyźnie. W ostatnim latach ważnym głosem w polsko-litewskiej naukowej dyskusji na temat wileńskiej AK jest praca Pawła Rokickiego, Glinciszki i Dubinki. Zbrodnie wojenne na Wileńszczyźnie w połowie 1944 roku i ich konsekwencje we wspótczesnych relacjach polsko-litewskich, Warszawa 2015. 
bytowych. Uzbrojeni ochotnicy w tych warunkach niekiedy nawiązywali współpracę z prywatnym biznesem, a nawet zorganizowanymi grupami przestępczymi. Kryzys dojrzał po wyborczych sukcesach lewicy, dla której hołubiony m.in. przez Landsbergisa i niemal ostentacyjnie prawicowy w sympatiach politycznych SKAT był niebezpiecznym obciążeniem. Już wcześniej potrzebę zreorganizowania formacji zgłaszał minister Butkevičius, zasiadający jeszcze w rządach Sajudisu, ale obecnie coraz bardziej skonfliktowany z Landsbergisem. Na początku 1993 r. rozpoczął wdrażanie projektu gruntownej reformy SKAT, skutkującej częściowym rozbrojeniem i zwalnianiem części ochotników ze służby.

Wśród ochotników z Kowna na ogólne niezadowolenie nałożyła się dodatkowo sytuacja konfliktowa. Miejscowy dowódca, Jonas Maskvytis, wdał się w spór z przestępcami oraz policją, za co groziła mu odpowiedzialność karna. W poczuciu krzywdy postanowił schronić się w położonym w głębi lasu gospodarstwie. Do Maskvytisa dołączyła grupa jego podkomendnych, z reguły kilkunastolatków. Przez kilka tygodni szeregi buntowników stale powiększały się. Miejscowa policja wolała unikać konfrontacji z dobrze uzbrojonymi i wyszkolonymi ochotnikami, a odpowiednie służby wojskowe pozostawały jeszcze w stadium organizacji. Kiedy sprawą zainteresowały się media, Maskvytis ogłosił, że przyświecają mu motywy polityczne. Przekonywał, że uciekł, gdyż nie chciał złożyć przysięgi na wierność prezydentowi wywodzącemu się z lewicy postkomunistycznej. Dowódca buntowników sugerował nawet, że celem było przeprowadzenie zamachu na Brazauskasa i zainicjowanie obalenia rządu. Maskvytis zaczął przez emisariuszy szukać poparcia prawicowych polityków. Niektórzy członkowie opozycji i publicyści wstrzymywali się z jednoznacznym potępieniem rebelii lub ją usprawiedliwiali. Zwolenników Landsbergisa, a nawet jego samego zaczęto oskarżać nawet o inspirowanie kryzysu. Minister Butkevičius opowiadał się za zdecydowaną rozprawą z buntownikami. Jednak prezydent i sejmowa większość byli innego zdania. Pacyfikacją incydentu zajęła się ostatecznie specjalna komisja parlamentarna. Dopiero pod koniec września przedstawicielom Sejmu udało się wynegocjować złożenie broni i powrót ochotników do koszar. W zamian obiecano, że nikt, kto w żaden inny sposób nie złamał prawa, nie zostanie pociągnięty do odpowiedzialności za bunt. Do buntu ochotników doszło w bardzo ważnym dla Litwy momencie, dlatego powszechnie spekulowano, czy kryzys nie miał charakteru dywersji. Landsbergis winą publicznie obarczał rosyjskie służby specjalne, które prowokując wystąpienie, próbowały zdestabilizować sytuację na Litwie i spowodować zatrzymanie ewakuacji własnych wojsk. Zwracał przy tym uwagę, że nieprzypadkowo niemal w tym samym czasie w Estonii miały miejsce podobne wydarzenia, również z udziałem formacji ochotniczej ${ }^{32}$.

32 V. Landsbergis, Viešoji informacija apie 1993 m. savanoriu akcija Pakauneje, Vilnius 2006, s. 10; E. Digryte, A. Butkevičius: savanoriu maištas - inspiruotas politikų, https://www.delfi. lt/news/daily/lithuania/abutkevicius-savanoriu-maistas-inspiruotas-politiku.d?id=11828239 
Stosunki z Rosją były kolejną płaszczyzną, na której opozycja nie zamierzała ustępować pola LDPP i prezydentowi. Tym bardziej że w kampaniach wyborczych na przełomie 1992 i 1993 r. lewica zwyciężyła m.in. pod hasłami „pragmatycznej” polityki wobec Moskwy. Na prawicy obawiano się, że może to oznaczać nawet zgodę zatrzymania rosyjskiego wojska $\mathrm{w}$ kraju w zamian za porozumienia gospodarcze. Lewicowe władze zamierzały wznowić rozmowy z Kremlem, zawieszone jeszcze przed wyborami parlamentarnymi. Obecnie zdaniem Brazauskasa na przeszkodzie stał już tylko skład ekipy negocjatorów. W marcu 1993 r. dekretem prezydenta polityk LDPP Virgilijus Bulovas zastąpił doświadczonego, lecz związanego z chadecją Česlovasa Stankevičiusa na stanowisku przewodniczącego zespołu do spraw pertraktacji z Rosją. W nowym składzie nie znalazł się ani jeden przedstawiciel opozycji. Prezydent przeforsował także kandydaturę Romualdasa Kozyrovičiusa na pierwszego ambasadora Litwy w Rosji (do tej pory stanowisko to pozostawało nieobsadzone). Centroprawica zinterpretowała powyższe fakty jako zapowiedź taktyki ustępstw wobec Moskwy. W maju, po siedmiu miesiącach przerwy, wznowiono jednak litewsko-rosyjskie negocjacje ${ }^{33}$.

Rosyjskie władze nie ukrywały zadowolenia $\mathrm{z}$ wyborczego zwycięstwa postkomunistów na Litwie. Otwarcie wyrażano przy tym nadzieję na pozyskanie Wilna do bliższej współpracy. Chodziło m.in. o „wyłuskanie” Litwy spośród niepokornych państw bałtyckich, a być może nawet jej akces do Wspólnoty Niepodległych Państw. Co prawda jeszcze w czerwcu 1992 r. litewska Rada Najwyższa zadecydowała, że Litwa nie będzie przystępować do żadnych postradzieckich wspólnot państwowych, ale Rosjanie wyraźnie liczyli, że nowa władza zmieni zdanie ${ }^{34}$. W marcu 1993 r. do litewskiej stolicy przybył minister spraw zagranicznych Rosji Andriej Kozyriew, który nie szczędził litewskim władzom pochwał za prowadzenie „realistycznej polityki” i przeciwstawiał ich pod tym względem „nacjonalistycznym” władzom Łotwy i Estonii. W tym samym czasie rosyjski minister obrony Paweł Graczow podczas spotkania Północnoatlantyckiej Rady Współpracy (NACC) w Brukseli przypomniał, że Rosja nie jest wcale zobligowana do opuszczenia pribałtyki ${ }^{35}$.

(dostęp: 12.09.2020); L. Vireliūnaitè, Dvidešimt metu po Jono Maskvyčio organizuoto Pakaunès savanoriu maišto: atsakymu i svarbius klausimus vis dar nera, https://www.15min.lt/naujiena/ aktualu/istorija/dvidesimt-metu-po-pakaunes-savanoriu-maisto-582-357811 (dostęp: 12.09.2020); w polskiej literaturze refleksje na temat buntu litewskich ochotników zostały zawarte we wspomnieniach ówczesnego attaché wojskowego w Wilnie: A. Firewicz, Litwa po raz drugi, Toruń 2001, s. 143-158.

${ }^{33}$ R. Sakalauskaitè, Pasiketimai derybu su Rusija delegacijoje: pozicija tikisi tęsti pradèta politika, opozicija i žvelgia nuoleidas Maskvai, „Lietuvos Rytas” (26 III 1993); szerzej zob. G. Vitkus, Diplomatine aporija. Tarptautine Lietuvos ir Rusijos santykiu normalizacijos perspektyva, Vilnius 2007, s. 36-38.

${ }^{34}$ Zob. polskie tłumaczenie aktu konstytucyjnego „O nieprzystępowaniu Republiki Litewskiej do postradzieckich związków wschodnich”, http://libr.sejm.gov.pl/tek01/txt/konst/litwa-d.html (dostęp: 12.09.2012).

35 H. Bukowiecka, Polityka Federacji Rosyjskiej w regionie Morza Bałtyckiego, Toruń 2012, s. 240. 
W maju bawiąc w Wilnie, zapewnił jednak, że jeśli chodzi o ewakuację z Litwy, to Rosja zamierza dotrzymać terminu wyznaczonego na koniec sierpnia. Pozostawił jednak Litwinów w niepewności, nie wykluczając opóźnienia z powodów organizacyjnych ${ }^{36}$.

Latem 1993 r. doszło do wyraźnego wzrostu napięcia między Rosją a państwami bałtyckimi. W Estonii przyjęto ustawę o cudzoziemcach, na mocy której duża część rosyjskojęzycznych mieszkańców została pozbawiona perspektyw naturalizacji. Projekt podobnej ustawy przyjął także rząd łotewski ${ }^{37}$. W odpowiedzi Rosja oskarżyła te państwa o bezpodstawne szykanowanie rosyjskiej mniejszości i wstrzymała negocjacje dotyczące wyprowadzenia z nich żołnierzy byłej Armii Radzieckiej. Niespodziewane problemy pojawiły się także w kontaktach z Moskwy z Wilnem. Prawicowa opozycja na Litwie stale naciskała na rząd i prezydenta, niemal wymuszając nieustępliwe stanowisko w sprawie dotrzymania rosyjskich zobowiązań ewakuacyjnych. Jednocześnie domagała się prowadzenia polityki solidarności z Łotwą i Estonią. Nie było również mowy o jakimkolwiek akcesie Litwy do poradzieckich struktur. Kiedy w Moskwie zorientowano się, że litewscy postkomuniści nie spełniają pokładanych w nich nadziei i nie są wystarczająco „pragmatyczni”, Kreml zastosował wypróbowaną metodę nacisku. W czerwcu i lipcu ponownie doszło m.in. do ograniczenia dostaw gazu ziemnego i ropy naftowej na Litwę pod pretekstem zaległości płatniczych.

Atmosferę miała oczyścić wizyta Brazauskasa w Moskwie, zapowiedziana na 5 sierpnia 1993 r. Litewski prezydent był przekonany, że w trakcie rozmowy z rosyjskim prezydentem Borysem Jelcynem uda się uzgodnić kompromisowe rozwiązania. Były I sekretarz KPL uważał się (słusznie) za eksperta od rzeczywistości poradzieckiej ${ }^{38}$. Preferował osobistą formę „załatwiania spraw” na Kremlu, najlepiej w cztery oczy, z pominięciem uciążliwej drogi służbowej. Jednakże temperatura antyrosyjskich nastrojów na Litwie gwałtownie wzrosła, a w demokratycznym państwie trzeba było liczyć się z nastawieniem opinii społecznej. W odpowiedzi na rosyjskie żądania spłaty długu już nie tylko sejmowa reprezentacja centroprawicy i sprzyjające jej media, ale nawet członkowie rządzącej partii zaczęli publicznie domagać się rekompensaty za lata "radzieckiej okupacji”, czyli okres pozostawania Litwy w ZSRR.

Brazauskas poprosił zatem Moskwę o przełożenie terminu wizyty. Jako oficjalny powód podano niedopracowanie tekstu ostatecznego porozumienia $\mathrm{w}$ sprawie

${ }^{36}$ R. Sakalauskaite, E. Ganusauskas, T. Juknevičius, Rusijos gynybos ministras P. Gračiovas už sutikima padèkojo lietuviškai ir garantavo kad kariuomene iš Lietuvos bus išventa laiku, „Lietuvos Rytas" (19 V 1993); H. Bukowiecka, op. cit., s. 240.

37 J. Sozański, Prawa mniejszości narodowych w niepodległej Litwie, Łotwie i Estonii, Warszawa 1998, s. 19, 62.

${ }^{38} \mathrm{~W}$ jednym z wywiadów podkreślał: „Mam trzydziestoletnie doświadczenie z biurokracją w Moskwie i wiem jak tam to działa", cyt. za: A. Lieven, Estonia, Latvia, Lithuania and the Path to Independence, New Haven 1993, s. 268. 
wycofania wojsk. Kolejną datę odwiedzin na Kremlu wyznaczono na 23 sierpnia. Do Moskwy niezwłocznie udał się zespół negocjatorów, który zaproponował m.in. wprowadzenie do porządku rozmów kwestii odszkodowań. Wilno oszacowało ich wysokość na astronomiczną kwotę 146 mld dolarów amerykańskich. Reakcja Rosji była stanowcza. Oskarżono litewskie władze o zamiar destabilizacji wzajemnych stosunków, a 18 sierpnia powiadomiono, że decyzją Jelcyna ewakuacja wojska z Litwy została wstrzymana. Wkrótce poinformowano także o jednostronnym zerwaniu wszelkich negocjacji przez Moskwę. Brazauskas w swoim stylu próbował jeszcze odciąć się od stanowiska zaprezentowanego przez oficjalną delegację litewską. Jednak opozycja zareagowała gwałtownymi atakami na prezydenta i zapowiedzią wszczęcia procedury impeachmentu w przypadku jakichkolwiek ustępstw wobec Rosji. W takiej sytuacji Brazauskas w wystąpieniu telewizyjnym ogłosił ponowne przełożenie wizyty w Rosji. Cała Litwa zamarła w oczekiwaniu na najgorsze. W relacjach z Moskwą powiało chłodem. W sierpniu 1993 r. Litwa stała się obiektem nagonki $w$ rosyjskich mediach, do tej pory specjalizujących się w dyskredytowaniu Łotwy i Estonii. Litewskie władze zapowiedziały nawet zwrócenie się o międzynarodową mediację. O kryzysie pisała prasa na całym świecie, wyrazy poparcia dla Wilna popłynęły z Waszyngtonu i stolic państw europejskich ${ }^{39}$.

W trudnej sytuacji Brazauskas postanowił przejąć inicjatywę bez oglądania się na rząd i Sejm. Napięcie w relacjach z Moskwą opadło po „bezpośredniej i szczerej" rozmowie telefonicznej litewskiego prezydenta z Jelcynem, przeprowadzonej 30 sierpnia. Uzgodniono, że oddziały rosyjskie opuszczą Litwę w przewidzianym terminie. Nie będą jednak traktowane jak wojska okupacyjne, ale zostaną pożegnane $\mathrm{z}$ wszelkimi honorami przez oficjalne delegacje, orkiestrę i morze kwiatów. Zapowiedziano także ustalenie nowej daty wizyty prezydenckiej w Moskwie oraz wznowienie negocjacji dotyczących uregulowania wzajemnych stosunków ${ }^{40}$. Brazauskas ogłosił dobre wieści za pośrednictwem mediów. Następnego dnia ostatnie jednostki wyjechały z Litwy ${ }^{41}$.

39 S. Erlanger, Russia-Lithuania Talks Over Troops at Impasse, „The New York Times” (24 VIII 1993); A. Račas, Lietuva-Rusija: tris savaites truksios įtampos, susijusios su sunkuties dèl Rusijos kariuomenes išvedimo pasirašimu rezultatai, „Lietuvos Rytas” (21 VIII 1993); idem, Rusijos ir Lietuvos santykiai: trys rugpjūčio dienos šaltojo karo link, „Lietuvos Rytas” (24 VIII 1993).

40 A. Brazauskas, op. cit., s. 276-277.

${ }^{41}$ K. Jauniškis, Po 54 metu Lietuva vél laisva!, „Lietuvos Rytas” (31 VIII 1993). W rzeczywistości w dawnych bazach pozostało wówczas jeszcze ok. 140 żołnierzy i oficerów pracujących przy ewakuacji sprzętu. Wyjechali do Rosji dopiero w połowie listopada 1993 r. Na mocy uzgodnień z Litwinami jeszcze przez pewien czas Rosjanie wykorzystywali do celów wojskowych także port w Kłajpedzie. We wrześniu 1993 r. amerykański Senat zagroził wstrzymaniem finansowej pomocy dla Rosji (2,5 mld dolarów), jeśli ta nie wznowi ewakuacji z Łotwy i Estonii. W połowie listopada wezwała do tego samego Rosję również rezolucja Zgromadzenia Ogólnego ONZ. Dążąc do przełamania niewygodnego impasu, Moskwa zdecydowała o wznowieniu negocjacji z Rygą i Tallinnem. Ewakuację rosyjskiego wojska z Łotwy i Estonii oficjalnie zakończono dopiero 31 sierpnia $1994 \mathrm{r}$. 
Powszechnemu uczuciu ulgi towarzyszyła lawina oskarżeń pod adresem prezydenta. Opozycja obwiniała go o przekroczenie kompetencji, rezygnację z zabiegów o rosyjskie odszkodowania lub choćby oficjalne potwierdzenie faktu okupacji Litwy w latach 1940-1991 ${ }^{42}$. Brazauskas kontrował, że gdyby nie wynegocjowany przez niego kompromis, obce wojska nadal stacjonowałyby na terytorium litewskim. Zażegnanie sierpniowego kryzysu uznawał za jedno ze swoich największych osiągnięć. Na początku września z pielgrzymką na Litwę przybył papież Jan Paweł II (większość mieszkańców Litwy to katolicy). Oprócz religijnego wizyta miała znaczenie polityczne. Co prawda przyjazd przygotowywano od wielu miesięcy, ale zbieżność z terminem ewakuacji rosyjskich wojsk miała wymiar symboliczny. Ranga i międzynarodowy autorytet gościa, który nie szczędził przyjaznych gestów pod adresem prezydenta, dodatkowo stanowiły ważną legitymację dla władzy postkomunistycznej. Papież wyraził radość $z$ odzyskania przez Litwinów wolności oraz nawoływał ich do duchowego pojednania ponad podziałami będącymi skutkiem długoletniej przynależności do ZSRR. Litewscy dziennikarze z entuzjazmem i dużą dozą przesady przekonywali, że w dniach pielgrzymki ojczyzna „znalazła się w centrum uwagi całego świata”43.

\section{Pod ciśnieniem wydarzeń w Rosji}

Latem 1993 r. w Rosji zaczął narastać kryzys konstytucyjny, który jesienią, na przełomie września i października, przerodził się w otwarty konflikt między prezydentem Jelcynem a częścią deputowanych do Rady Najwyższej. Obie strony wezwały swoich zwolenników do walki. Oddziały wierne Jelcynowi 4 października 1993 r. przypuściły szturm na tzw. moskiewski Biały Dom, czyli siedzibę Rady Najwyższej. Ostateczne zwycięstwo utwierdziło pozycję rosyjskiego prezydenta, ale także wzmocniło wspierające go kręgi wojskowe, niechętne dalszym ustępstwom wobec Zachodu. W rezultacie istotnej zmianie uległ polityczny klimat relacji także z państwami byłego bloku sowieckiego i dawnymi republikami związkowymi, które zdążyły odciąć się od związków z Kremlem. Niemal nazajutrz po zażegnaniu wewnętrznego kryzysu Rosja zaczęła silniej podkreślać, że poradziecki obszar (tzw. bliska zagranica) uznaje za sferę swoich żywotnych interesów i w razie potrzeby nie zawaha się przed zbrojną interwencją. Wśród potencjalnych celów wymieniano dawną pribałtykę $e^{44}$.

${ }^{42}$ Lietuvos Respublikos Seimo Stenogramos, posiedzenie 2, 10 IX 1993, https://e-seimas.lrs.lt/rs/ legalact/TAK/TAIS.236827/\#zyma_3s2porus (dostęp: 13.09.2020).

43 Pirmasis popiežiaus vizitas: Lietuva buvo pasaulio demesio centre, https://kauno.diena.lt/naujienos/lietuva/salies-pulsas/pirmasis-popieziaus-vizitas-lietuva-pasaulio-demesio-centre- 412221 (dostęp: 13.09.2020); 15min primena: kur, viešédamas Lietuvoje, lankèsi Jonas Paulius II?, https:// www.15min.lt/naujiena/aktualu/lietuva/15min-primena-kur-lankydamasis-lietuvoje-lankesi-jonaspaulius-ii-56-889434 (dostęp: 13.09.2020).

44 R. Śmigielski, Doktryna wojenna Federacji Rosyjskiej, „Sprawy Wschodnie” (2004), nr 2-3, s. 165168; T.W. Grabowski, Rosyjska siła. Siły zbrojne i główne problemy polityki obronnej Federacji Rosyjskiej w latach 1991-2010, Częstochowa 2011, s. 65. 
W Wilnie bardzo uważnie śledzono moskiewskie wydarzenia oraz ich bezpośrednie następstwa. Mimo że rosyjskie pogróżki były skierowane głównie wobec Estonii i Łotwy, to również na Litwie doskonale zdawano sobie sprawę z niebezpieczeństwa. Litewski prezydent deklarował pełne poparcie dla Jelcyna, jednak rozwój sytuacji w Rosji napawał niepokojem. Sekwencja wydarzeń budziła obawę o przyszłość świeżo odzyskanej niepodległości. Aż zanadto jasne stało się, że pozostanie przy Brazauskasowskiej idei „pomostu” między Wschodem a Zachodem skazywało Litwę na pozostawanie w „szarej strefie”, gdzie była łatwym celem rosyjskich dążeń neoimperialnych. W nowych warunkach już nie tylko większość sił opozycyjnych, ale także wpływowa grupa działaczy rządzącej partii dawała wyraz przekonaniu, że jedynie przyjęcie pełnej opcji zachodniej może zapewnić litewskiemu państwu gwarancje bezpieczeństwa. Rzecznikiem korekty polityki zagranicznej był m.in. nowy (mianowany w końcu października 1993 r.) minister obrony, Linas Linkevičius. Podobne postulaty zgłaszał szef dyplomacji Povylas Gylys, do niedawna sceptyczny wobec jednoznacznie prozachodniego kierunku. Jeszcze w trakcie październikowych starć moskiewskich liderzy wszystkich reprezentowanych w Sejmie partii politycznych wystosowali do prezydenta memorandum w sprawie rozpoczęcia starań o członkostwo w Pakcie Północnoatlantyckim ${ }^{45}$. W połowie października Brazauskas przyjął sygnatariuszy listu. Prezydent poparł pomysł opracowania nowej strategii polityki zagranicznej. Uchylił się jednak od zajęcia jednoznacznego stanowiska w sprawie przystąpienia do NATO. Zaproponował, aby przede wszystkim wypowiedział się $\mathrm{w}$ tej sprawie parlament.

$\mathrm{Na}$ początku listopada 1993 r. doszło do kilkakrotnie odkładanej wizyty Brazauskasa w Moskwie i spotkania z Jelcynem. Rosyjski prezydent dosyć niespodziewanie zaproponował wówczas uregulowanie sprawy wojskowego tranzytu przez terytorium litewskie do obwodu kaliningradzkiego. Zgodnie z porozumieniami z 1992 r. Rosja powinna była uzyskiwać formalną zgodę na każdorazowy przejazd transportu wojskowego przez terytorium litewskie. Jednak dotychczas obie strony niezbyt rygorystycznie przestrzegały tych ustaleń. Litwini przede wszystkim nie chcieli dawać Rosjanom pretekstu do wstrzymywania ewakuacji żołnierzy. Dopiero po jej zakończeniu Wilno poinformowało o zamiarze wprowadzenia szeregu nowych ograniczeń celnych i przewozowych. W rozmowie $\mathrm{z}$ Brazauskasem Jelcyn zaoferował korzystne umowy gospodarcze w zamian za litewskie ustępstwa w sprawie tranzytu. Litewski prezydent uznał, że propozycja jest atrakcyjna zwłaszcza wobec kłopotów ekonomicznych jego kraju. Rozmówcy uzgodnili zatem, że konkretne umowy zostaną opracowane w niemal ekspresowym tempie dwóch tygodni. Pakiet porozumień podpisano następnie podczas roboczej wizyty Wiktora Czernomyrdina, premiera rządu rosyjskiego w litewskiej

${ }^{45}$ Lietuvos Respublikos Prezidentui partiju kreipimasis dèl Lietuvos Respublikos integravimosi i NATO, 5 X 1993, http://www.urm.lt/uploads/default/documents/uzienio_politika/NATO/ pareiskimas2.jpg (dostęp: 15.09.2020). 
stolicy 18 listopada. Ustalono wówczas m.in., że jeszcze co najmniej rok Rosja będzie mogła korzystać $\mathrm{z}$ litewskich linii kolejowych oraz kłajpedzkiego portu na dogodnych dla siebie warunkach ${ }^{46}$.

Mimo że litewski prezydent i rząd interpretowali umowy jako sukces, polityczni komentatorzy, opozycja, a nawet niektórzy politycy LDPP bili na alarm. Dostrzegano, że w kontekście niedawnych wypadków powiązanie kwestii strategicznego bezpieczeństwa $\mathrm{z}$ doraźnymi ustaleniami gospodarczymi było wyjątkowo niefortunnym rozwiązaniem. Dodatkowo umowy gospodarcze nie gwarantowały długofalowego rozstrzygnięcia, a utrwalały niebezpieczny stan zależności Litwy od Rosji. Tym bardziej paląca stawała się potrzeba intensyfikacji starań o zmianę polityki zagranicznej oraz przekonanie Brazauskasa do wsparcia nowego kursu.

W kontekście prozachodnich aspiracji problematyczna dla Wilna była zwłaszcza sprawa stosunków z Warszawą. Polska od dawna zabiegała o udział w euroatlantyckiej integracji, notując na tym polu nawet pewne sukcesy. Wielu litewskich polityków wywodzących się z prawego skrzydła Sajudisu uznawało, że w kwestii rozwoju cywilizacyjnego i bezpieczeństwa ich ojczyzna powinna szukać oparcia raczej w państwach skandynawskich niż środkowoeuropejskich, a już najmniej liczyć na Polskę. Jednakże w kontekście wydarzeń w Rosji skandynawski model niezaangażowania stawał się coraz mniej inspirujący. Oczywiste stawało się, że najkrótsza droga Litwy na Zachód będzie wiodła przez Polskę nie tylko w znaczeniu ściśle geograficznym. Jeszcze w październiku 1993 r., niemal równolegle do listu nawołującego do rozpoczęcia starań o członkostwo w NATO, partie opozycyjne sygnowały drugi list adresowany do najwyższych władz. Wyrażono w nim ogólne poparcie dla budowy dobrych relacji z Polską. Zdaniem sygnatariuszy jedynie postawa niektórych przedstawicieli polskiej mniejszości narodowej na Litwie torpedowała zbliżenie obu państw ${ }^{47}$. Mimo nieco pokrętnej logiki zastosowanej w tym dokumencie perspektywa oparcia się o Polskę wydawała się coraz bardziej realna nawet $\mathrm{w}$ opinii centroprawicy. Tym bardziej że we wrześniowych wyborach $\mathrm{w}$ Polsce władza trafiła $\mathrm{w}$ ręce ugrupowania wywodzącego się $\mathrm{z}$ dawnej partii komunistycznej. Zmiana paradoksalnie była korzystna, gdyż mogła zapowiadać pragmatyczne podejście polskich negocjatorów do najbardziej spornej kwestii, jaką w opinii litewskich partii opozycyjnych pozostawała ocena historii.

${ }^{46}$ R. Sakalauskaitè, Lietuvos ir Rusijos priezidentai Kremliuje pasidalio prisiminimais, o konkrečiaus susitavimus atidejoakičiai, „Lietuvos Rytas” (5 XI 1993); eadem, Kodèl ketvertadeni Kremliuje nebuvo pasirašytos Lietuvos ir Rusijos sutartys ir susitarimas?, „Lietuvos Rytas” (6 XI 1993); Č. Laurinavičius, R. Lopata, V. Sirutavičius, Rusijos Federacijos karinis tranzitas per Lietuvos respublikos teritorija, „Politologija” (2002), nr 4, s. 17-18; G. Vitkus, op. cit., s. 40-41.

47 Rüpestis dèl rytu Lietuvos, „Lietuvos Aidas” (22 X 1993). W liście zwracano uwagę, że to reprezentanci polskiej mniejszości zabiegali np. o nieustępliwe stanowisko Warszawy w sprawie litewskich postulatów dotyczących interpretacji historii. Zdaniem sygnatariuszy miało to świadczyć o ponownym uaktywnieniu się „autonomistów” dążących do oderwania Wileńszczyzny od Litwy. W związku z tym nawoływano władze do zaostrzenia polityki wobec litewskich Polaków. Szerzej zob. B. Jundo-Kaliszewska, op. cit., s. 362. 
Kierunek rozwoju stosunków litewsko-rosyjskich w październiku i listopadzie jeszcze wzmacniał przekonanie litewskich elit, reprezentantów zarówno opozycji, jak rządzącej partii, o potrzebie przejęcia inicjatywy w kontaktach z Polską. Tym bardziej że Zachód dawał jasno do zrozumienia, iż oczekuje od państw aspirujących definitywnego uregulowania spornych kwestii $\mathrm{w}$ relacjach $\mathrm{z}$ sąsiadami. Wskutek uprawiania polityki sabotowania porozumienia z Polską Litwini coraz bardziej byli postrzegani jako niezdolni do kompromisu nacjonaliści, kierujący się przede wszystkim resentymentami ${ }^{48}$. Na początku grudnia 1993 r. w Brukseli doszło do spotkania szefów dyplomacji Litwy i Polski, Gylysa i Andrzeja Olechowskiego. Konsultacje dotyczyły m.in. nawiązania współpracy w dążeniu do NATO i w relacjach z Rosją. Litewski minister zaproponował odblokowanie prac nad traktatem, co jego polski odpowiednik powitał z zadowoleniem. Ustalono, że Gylys i Olechowski będą odtąd osobiście nadzorować toczące się negocjacje. Chciano w ten sposób osłonić prowadzone rozmowy przed możliwą ingerencją politycznych radykałów operujących hasłami obrony zagrożonego interesu narodowego ${ }^{49}$. W połowie grudnia do Warszawy przybył przewodniczący litewskiego Sejmu Juršènas, który w rozmowach z polskimi władzami nie tylko uzgodnił ogólną formułę przyszłego układu, ale też przemawiając z trybuny parlamentarnej, wyraził nadzieję na nawiązanie ściślejszej współpracy $\mathrm{w}$ drodze na Zachód ${ }^{50}$. Jasno dał do zrozumienia, że Litwa liczy na polskie wsparcie, w zamian oferując długo wyczekiwaną ugodę międzypaństwową.

W tym samym czasie Brazauskas uczestniczył w szczycie państw bałtyckich odbywającym się w Tallinnie. Wtórując prezydentom Łotwy Guntisowi Ulmanisowi i Estonii Lennartowi Meriemu, opowiedział się wówczas za rozpoczęciem skoordynowanych starań o członkostwo w NATO i Unii Europejskiej ${ }^{51}$. Komunikat opublikowany po spotkaniu, a także misja Juršènasa, bliskiego współpracownika Brazauskasa, wskazywały, że ośrodek prezydencki podjął decyzję w sprawie nowego kierunku polityki zagranicznej. W drugiej połowie grudnia kancelaria prezydenta zainicjowała szereg konsultacji z udziałem głowy państwa, liderów wszystkich litewskich stronnictw sejmowych i szefa dyplomacji. Tuż przed świętami Bożego Narodzenia odbyła się parlamentarna debata poświęcona polityce zagranicznej. Obecny na sali obrad Brazauskas opowiedział się za obraniem prozachodniego kursu, podobnie jak reprezentanci stronnictw. Sejm przyjął rezolucję, w której rekomendował władzy wykonawczej wystąpienie z oficjalnym wnioskiem o przyjęcie do $\mathrm{NATO}^{52}$.

48 E. Pukinas, Lietuva vizomis priveria Rytų vartus ir žada beltis i NATO duryis, „Lietuvos Rytas” (29 X 1993).

49 V. Sirutavičius, Lietuviai ir lietuvos Lenkai..., s. 393-394.

50 Sejm Rzeczpospolitej Polskiej, 2 kadencja, 7 posiedzenie, 3 dzień (17 XII 1993), Przemówienie Przewodniczącego Sejmu Republiki Litewskiej Česlovasa Juršenasa, http://orka2.sejm.gov.pl/ Debata2.nsf (dostęp: 16.09.2020).

51 Trys prezidentai paragino NATO atsigrężti į Rytų Europa, „Lietuvos Rytas” (16 XII 1993).

52 Lietuvos Respublikos Seimo Stenogramos, posiedzenie 56, 22 XII 1993, https://e-seimas.lrs.lt/ portal/legalAct/lt/TAK/TAIS.237050\#zyma_3s56podisk (dostęp: 14.11.2020). 
Na początku stycznia $1994 \mathrm{r}$. Brazauskas spełnił to życzenie. Następnie już do końca swej prezydenckiej kadencji był orędownikiem i twarzą litewskich zabiegów o euroatlantycką integrację. W $1994 \mathrm{r}$. sfinalizowano również traktat „O przyjaznych stosunkach i dobrosąsiedzkiej współpracy”. W porozumieniu ostatecznie nie zawarto deklaracji historycznej w kształcie postulowanym wcześniej przez litewską centroprawicę ${ }^{53}$. Zamieszczono za to słowa o uznaniu Warszawy i Wilna za stolice obu państw. Tę ostatnią niecodzienną formułę z preambuły strona litewska potraktowała jako swój sukces ${ }^{54}$.

\section{Zakończenie}

Litewski „długi rok 1993” obfitował w ważne i dramatyczne wydarzenia, których konsekwencje okazały się kluczowe dla świeżo odzyskanej niepodległości i strategicznego kierunku rozwoju państwa. W wyniku wyborczego zwycięstwa lewicy postkomunistycznej z przełomu 1992 i 1993 r. krajowa scena polityczna uległa przewartościowaniu oraz polaryzacji. Porażka przypieczętowała dekompozycję Sajudisu i przyspieszyła proces klarowania się centroprawicowych stronnictw politycznych. Współdziałając na forum parlamentu, opozycja potrafiła zaskakująco skutecznie wpływać na pracę zwalczanego przez siebie rządu oraz prezydenta. Ostatecznie pod wpływem widma zagrożenia rosyjskiego oba czołowe bloki polityczne zdecydowały się na kompromis na gruncie polityki zagranicznej. Według nadrzędnego celu, jakim było rozpoczęcie starań o członkostwo w NATO, centroprawica

53 Stanowisko zostało najpełniej zaprezentowane w wystąpieniu sejmowym Landsbergisa z 15 sierpnia 1994 r., wygłoszonym przy okazji debaty ratyfikacyjnej. Mówca zaznaczył, że w obecnej chwili potrzeba zawarcia traktatu nie budziła już wątpliwości. Wyraził jednak żal, że Polska „nie zdołała przekroczyć tej psychologicznej bariery, aby choć słówkiem przeprosić za krzywdy wyrządzone słabszemu sąsiadowi, jak to na przykład uczyniły Niemcy wobec Polski”. Winą za owe niedociągnięcia obarczył nie tylko stronę polską, ale także litewskich postkomunistów, którzy nie dość zadbali o interesy narodowe. W konkluzji opowiedział się wszakże za traktatem jako porozumieniem, które osłabiało „wpływy strony trzeciej” (tj. Rosji), a także odpowiadało zapotrzebowaniu nowoczesnej Europy. Lietuvos Respublikos Seimo Stenogramos, posiedzenie $15 \mathrm{X}$ 1994, https://e-seimas.lrs.lt/rs/legalact/TAK/TAIS.238895/\#zyma_5s5polenk (dostęp: 15.09.2020); por. V. Landsbergis, Przemówienie wygłoszone w Sejmie Litewskim 15 września 1994 o traktacie polsko-litewskim, w: Pozostawione historii. Litwini o Polsce i Polakach, red. K. Korzeniewska, V. Sirutavičius, Kraków 1999, s. 168-171.

${ }^{54}$ A. Brazauskas, op. cit., s. 309; V. Sirutavičius, Lietuviai ir lietuvos Lenkai..., s. 407-414. W traktacie strony wyraziły jedynie „żal z powodu konfliktów między obydwoma państwami po zakończeniu I wojny światowej” oraz potępiły „używanie przemocy, które się zdarzało w stosunkach wzajemnych obu narodów”. Lietuvos Respublikos ir Lenkijos Respublikos sutartis „Dèl draugišku santykiu ir gero kaimyninio bendradarbiavimo", https://e-seimas.lrs.lt/portal/legalAct/lt/TAD/ TAIS.11154 (dostęp: 20.09.2020); polski tekst traktatu: http://www.lex.pl/du-akt/-/akt/dz-u-199515-71 (20.09.2020); analiza prawna tekstu w: J. Sobczak, Potomkowie Lecha i Giedymina. Stosunki polityczne między Litwa a Polska w pierwszych latach odrodzenia państwa litewskiego, Poznań 2009, s. $147-157$. 
(głównie konserwatyści i chadecy) zaakceptowała konieczność zawarcia długo kontestowanego porozumienia z Polską. Z kolei lewica postkomunistyczna porzuciła ideę neutralności Litwy na rzecz orientacji zachodniej. Z perspektywy czasu widać, że zwłaszcza kompromis sfinalizowany w końcówce 1993 r. co najmniej na kilka dziesięcioleci przesądził o dziejach kraju. Prozachodni kierunek był utrzymywany przez wszystkie ekipy rządzące w Wilnie. Traktat z Polską, zawarty w 1994 r., poważnie ułatwił Litwie zabiegi o integrację euroatlantycką, zapoczątkował również okres bliskiej kooperacji politycznej między obydwoma państwami - wyjątkowej w dziejach XX w. W 2004 r. Litwa (wraz z Łotwą i Estonią oraz gronem innych państw środkowej i południowej Europy) stała się członkiem NATO i Unii Europejskiej. Premierem rządu litewskiego był wówczas Algirdas Brazauskas, natomiast Vytautas Landsbergis w tym samym roku został deputowanym do Parlamentu Europejskiego. Litwa powróciła do zachodniego świata, którego częścią pozostaje.

\section{Lithuania 1993: Pivotal Year of Independence}

\section{Abstract}

The year 1993 in Lithuania began with the election triumphs of the post-communist leftist party. The emergence of a new system of political forces called into question the current direction of the country's development. Contrary to some fears expressed both in the country and in the West, the new government did not aim at the recidivism of communism, nor did it want to force the country into the arms of Russia. From the beginning, the rulers focused mainly on improving the extremely difficult economic situation. On the other hand, the opposition was left with a great deal of activity in foreign policy. This situation was partly due to the lack of a clear strategy of the leftist party and the persistent use of political culture. Taking advantage of the situation, the centre-rightist parties for many months successfully influenced, in particular, the state of relations with Poland, and in the summer of 1993 also with Russia. However, the left-wing government also noted success in finalising the evacuation of Russian troops from the country and was able to take advantage of the Pope's visit to Lithuania for propaganda purposes. In the fall of 1993, Lithuania found itself in a difficult position due to developments in Russia. In these circumstances, the Lithuanian elite decided, over political divisions, to take a pro-Western course in foreign policy. The intention was to rely on Poland to become a member of NATO and the European Union. For this reason, works on the treaty with Poland was unblocked.

\section{Литва 1993: ключевой год независимости}

\section{Аннотация}

1993 год в Литве начался с избирательных триумфов посткоммунистических левых. Формирование новой расстановки политических сил ставило под вопрос прежнее направление развития государства. Вопреки некоторым опасениям, выражавшимся как в стране, так и на Западе, новая власть не стремилась, однако, к рецидиву коммунизма и не хотела толкать страну в объятия России. С самого начала власть имущие сосредо- 
точились, главным образом, на улучшении крайне сложной экономической ситуации. В то время как в области внешней политики большое поприще было отведено для оппозиции. Такая ситуация, отчасти, была обусловлена отсутствием четкой стратегии на стороне левых, но и устоявшимися узусами в области политической культуры. Пользуясь ситуацией, в течение многих месяцев правоцентристы особенно эффективно влияли на состояние отношений с Польшей, а летом 1993 года - и с Россией. Однако власть, состоящая из левых политиков, также добилась успеха в виде завершения вывода российских войск из страны, а также смогла пропагандистски воспользоваться визитом Папы Римского в Литву. Осенью 1993 года Литва оказалась в трудном положении из-за развития событий в России. В этих условиях литовские элиты решили, несмотря на политические разногласия, о необходимости отстаивать прозападный курс во внешней политике. Они намеревались опираться на Польшу в попытках получить членство в НАТО и Европейском Союзе. По этой причине были разблокированы работы по договору с Польшей.

\section{Bibliografia}

\section{Źródła drukowane}

A. Žuko klausimai išrinktam LR Prezidentui A. Brazauskui, „Respublika” (17 II 1993).

Adamkus V., Alma i Valdas. Nasz los - Litwa, Toruń 2008.

Algirdo Brazausko vizitai i Rytus, „Lietuvos Rytas” (6 XI 1993).

Brazauskas A., Penkeri Prezidento metai, Vilnius 2000.

Bukinas E., Buvusio vienuolyno skiautai kaimyniniu šauliu premjerus paskatino galvoti apie ateiti, o praeiti polikti istorikams, „Lietuvos Rytas” (9 I 1993).

Bukinas E., Pavasaris Baltarusijos premjero vizitas i Lietuvą apti role dvišaliu santykių ledus, „Lietuvos Rytas” (17 III 1993).

Firewicz A., Litwa po raz drugi, Toruń 2001.

Gromadzki G., Litewski syndrom, „Gazeta Wyborcza” (3 III 1996).

Iš A. Brazausko, kandidato ị Lietuvos Respublikos Prezidentus, programos, „Respublika” (28 I 1993).

Jablonskaitè D., Lito dvidešimtmetis - su mirties ženklu, http://www.15min.lt/naujiena/aktualu/ istorija/lito-dvidesimtmetis-su-mirties-zenklu-582-347247 (dostęp: 4.09.2020).

Jauniškis K., Po 54 metų Lietuva vél laisva!, „Lietuvos Rytas” (31 VIII 1993).

Jauniškis K., Prezidento rinkimu išvakarèse ir žigsniai atgal gali būti naudingi ateičiai?, „Lietuvos Rytas" (5 I 1993).

Landsbergis V., Przemówienie wygłoszone w Sejmie Litewskim 15 września 1994 o traktacie polsko-litewskim, w: Pozostawione historii. Litwini o Polsce i Polakach, red. K. Korzeniewska, V. Sirutavičius, Kraków 1999, s. 168-171.

Lietuvos Respublikos ir Lenkijos Respublikos sutartis „Dèl draugišku santykiu ir gero kaimyninio bendradarbiavimo", https://e-seimas.lrs.lt/portal/legalAct/lt/TAD/TAIS.11154 (dostęp: 20.09.2020); polski tekst traktatu: http://www.lex.pl/du-akt/-/akt/dz-u-1995-15-71 (dostęp: 20.09.2020).

Lietuvos Respublikos Konstitucija, http://www3.lrs.lt/home/Konstitucija/Konstitucija.htm\#NESIJUNGIMO (dostęp: 30.08.2020).

Lietuvos Respublikos Prezidentui partiju kreipimasis dèl Lietuvos Respublikos integravimosi i NATO, 5 X 1993, http://www.urm.lt/uploads/default/documents/uzienio_politika/NATO/ pareiskimas2.jpg (dostęp: 15.09.2020). 
Lietuvos Respublikos Seimo Stenogramos, posiedzenie 1, 25 XI 1992, https://e-seimas.lrs.lt/ portal/legalAct/lt/TAK/TAIS.235315 (dostęp: 31.08.2020).

Lietuvos Respublikos Seimo Stenogramos, posiedzenie 15 X 1994, https://e-seimas.lrs.lt/rs/ legalact/TAK/TAIS.238895/\#zyma_5s5polenk (dostęp: 15.09.2020).

Lietuvos Respublikos Seimo Stenogramos, posiedzenie 2, 10 IX 1993, https://e-seimas.lrs.lt/rs/ legalact/TAK/TAIS.236827/\#zyma_3s2porus (dostęp: 13.09.2020).

Lietuvos Respublikos Seimo Stenogramos, posiedzenie 56, 22 XII 1993, https://e-seimas.lrs.lt/ portal/legalAct/lt/TAK/TAIS.237050\#zyma_3s56podisk (dostęp: 14.09.2020).

Lietuvos Respublikos Vyriausybès ir Ukrainos Vyriausybess susitarimas „Dèl bendradarbiavimo principu ir tarpusavio santykiu salygu transporto srityje”, 7 VII 1993, https://e-seimas.lrs. lt/portal/legalAct/lt/TAD/TAIS.11215 (dostęp: 8.09.2020).

Lietuvos užsienio politika: romantikai užleidžia vieta pragmatikams? (rozmowa z P. Gylysem), „Lietuvos Rytas” (28 I 1993).

O nieprzystępowaniu Republiki Litewskiej do postradzieckich związków wschodnich, http://libr. sejm.gov.pl/tek01/txt/konst/litwa-d.html (dostęp: 12.09.2012).

Ozolas R., Lietuva 1990-1993 metais. Istorija karštomis pédomis, Vilnius 2008.

Pasirašyti Lietuvos ir Baltorusijos susitarimai, „Respublika” (17 III 1992).

Pirmasis Seimo posédis: iškilmiu daina su ateitis ir praeitis priedainiais, „Lietuvos Rytas” (26 XI 1992).

Prezidentas garantavo Krikščioniu demokratu partijos vadovams, kad politika Rusijos atžvilgiu nesikeičia, „Lietuvos Rytas” (2 VII 1993).

Pukinas R., Lietuva vizomis priveria Rytu vartus ir žada beltis į NATO duryis, „Lietuvos Rytas” (29 X 1993)

Račas A., Prezidento kritikuotas užsienio reikalu ministras atsistadynti neketina, „Lietuvos Rytas” (18 VI 1993).

Rūpestis dèl rytu Lietuvos, „Lietuvos Aidas” (22 X 1993).

Sakalauskaitè R., Algirdas Brazauskas: dabartines politinès audros ramus miego nerumsčia, „Lietuvos Rytas" (11 II 1993).

Sakalauskaitė R., Ganusauskas E., Juknevičius T., Rusijos gynybos ministras P. Gračiovas už sutikima padèkojo lietuviškai ir garantavo kad kariuomenè iš Lietuvos bus išventa laiku, „Lietuvos Rytas” (19 V 1993).

Sakalauskaitė R., Kodèl ketvertadeni Kremliuje nebuvo pasirašytos Lietuvos ir Rusijos sutartys ir susitarimas?, „Lietuvos Rytas” (6 XI 1993).

Sakalauskaite R., Lietuva ir Ukraina: dvieju šaliu interesu erdvé - nuo Baltijos iki Juodosios jūros, „Lietuvos Rytas” (8 VII 1993).

Sakalauskaitè R., Lietuvos ir Rusijos priezidentai Kremliuje pasidalio prisiminimais, o konkrečiaus susitavimus atidejoakičiai, „Lietuvos Rytas” (5 XI 1993).

Sakalauskaitè R., Pasiketimai derybu su Rusija delegacijoje: pozicija tikisi tęsti pradèta politika, opozicija i žvelgia nuoleidas Maskvai, „Lietuvos Rytas” (26 III 1993).

Sejm Rzeczpospolitej Polskiej, 2 kadencja, 7 posiedzenie, 3 dzień (17 XII 1993), Przemówienie Przewodniczącego Sejmu Republiki Litewskiej Česlovasa Juršenasa, http://orka2.sejm.gov. pl/Debata2.nsf (dostęp: 16.09.2020).

Sutartys su Rusija pasirešytos, gal greit bus ir naftos, „Lietuvos Rytas” (13 X 1992).

Trys prezidentai paragino NATO atsigręžti ị Rytu Europa, „Lietuvos Rytas” (16 XII 1993).

\section{Opracowania}

15min primena: kur, viešèdamas Lietuvoje, lankèsi Jonas Paulius II?, https://www.15min.lt/ naujiena/aktualu/lietuva/15min-primena-kur-lankydamasis-lietuvoje-lankesi-jonas-paulius-ii-56-889434 (dostęp: 13.09.2020). 
Bereś W. (współpraca J.J. Komar), Okińczyc wileński autorytet. Opowieść o wolnej Litwie, Warszawa 2015.

Bukowiecka H., Polityka Federacji Rosyjskiej w regionie Morza Bałtyckiego, Toruń 2012.

Digrytė E., A. Butkevičius: savanoriu maištas - inspiruotas politiku, https://www.delfi.lt/news/ daily/lithuania/abutkevicius-savanoriu-maistas-inspiruotas-politiku.d?id=11828239 (dostęp: 12.09.2020).

Erlanger E., Russia-Lithuania Talks Over Troops at Impasse, „The New York Times” (24 VIII 1993).

Godlewski T., Udziat prezydenta Republiki Litewskiej w ustawodawstwie, „Przegląd Prawa Konstytucyjnego" (2014), nr 3.

Grabowski T., Rosyjska siła. Siły zbrojne i główne problemy polityki obronnej Federacji Rosyjskiej w latach 1991-2010, Częstochowa 2011.

Grybkauskas S., Tamošaitis M., Žmogus, jungęs epochas. Algirdo Brazausko politinè biografija, Vilnius 2019.

Jundo-Kaliszewska B., Zakładnicy historii. Mniejszość polska w postradzieckiej Litwie, Łódź 2019.

Kašauskienė V., Lietuvos Respublikos vyriausybès. Jų kaita ir veiklos bruožai 1990-2007, Vilnius 2007.

Kręcisz W., Republika Litewska, w: Ustroje państw współczesnych, t. 2, red. E. Gdulewicz, Lublin 2002, s. 102-134.

Landsbergis V., Viešoji informacija apie 1993 m. savanoriu akcija Pakaunèje, Vilnius 2006.

Laurinavičius Č., Lopata R., Sirutavičius V., Rusijos Federacijos karinis tranzitas per Lietuvos respublikos teritorija, „Politologija” (2002), nr 4.

Lieven A., Estonia, Latvia, Lithuania and the Path to Independence, New Haven 1993.

Lukošaitis A., Prezidentas Lietuvos politineje sistemoje: vietos ir galio paieškos, „Politologija” (1998), nr 2.

Martikonis R., Penkeri Lietuvos ir Europos Sajungos santykiu metai, „Politologija” (1996), nr 8.

Nekrašas E., Kritiniai pamąstai apie Lietuvos užsienio politiką, „Politologija” (2009), nr 2.

Nekrašas E., Legislature and the Executive in Foreign Policy Making, Vilnius 1994.

Nekrašas E., Lithuanian Political System and Foreign Policy Decision Making, „Lithuanian Foreign Policy Review” (1999), nr 4.

Paulauskas K., Kieno saugumas? Kuri tapatybè? Kritinès saugumo studijos ir Lietuvos užsienio politika, Vilnius 2010.

Pirmasis popiežiaus vizitas: Lietuva buvo pasaulio demesio centre, https://kauno.diena.lt/naujienos/lietuva/salies-pulsas/pirmasis-popieziaus-vizitas-lietuva-pasaulio-demesio-centre-412221 (dostęp: 13.09.2020).

Pugačiauskas V., Lithuania's semi-Presidential Model: Prospects For The Stability of The Inter-Institutional Relations, „Lithuanian Political Science Yearbook” (2002, Vilnius 2003).

Pukenè R., Neįtiketina Bronislovo Lubio gyvenimo istorija: draugai, turtai, klaidos ir testamento paslaptis, https://www.delfi.lt/multimedija/k11/neitiketina-bronislovo-lubio-gyvenimo-istorija-draugai-turtai-klaidos-ir-testamento-paslaptis.d?id=83415867 (dostęp: 2.11.2020).

Rokicki P., Glinciszki i Dubinki. Zbrodnie wojenne na Wileńszczyźnie w połowie 1944 roku i ich konsekwencje we współczesnych relacjach polsko-litewskich, Warszawa 2015.

Sirutavičius V., Lietuviai ir lietuvos Lenkai, Lietuva ir Lenkija 1988-1994 metais, Vilnius 2017.

Sidorkiewicz K., Od trudnego sasiedztwa po strategiczne partnerstwo. Polska wobec Litwy w latach 1990-2004, Elbląg 2014.

Sobczak J., Potomkowie Lecha i Giedymina. Stosunki polityczne między Litwa a Polska w pierwszych latach odrodzenia państwa litewskiego, Poznań 2009.

Sobczak J., Studia nad wyborami prezydenckimi i parlamentarnymi na Litwie i Białorusi, Poznań 1997.

Sozański J., Prawa mniejszości narodowych w niepodległej Litwie, Łotwie i Estonii, Warszawa 1998.

Stefanowicz M., Polityka etniczna Litwy w latach 1990-2004, Kraków 2019. 
Surgailis G., Rusijos kariuomenes išvedimas 1990-1993, Vilnius 2005.

Śmigielski R., Doktryna wojenna Federacji Rosyjskiej, „Sprawy Wschodnie” (2004), nr 2-3.

Vainauskienè B., Skandalingoji lito istorija, Vilnius 2003.

Vardys V., Lietuvos politine kultūra ir laiko reikalavimai, http://www.partizanai.org/i-laisve1993-116-153/3072-lietuvos-politine-kultura-ir-laiko-reikalavimai (dostęp: 11.09.2020).

Vireliūnaite L., Dvidešimt mety po Jono Maskvyčio organizuoto Pakaunès savanoriu maišto: atsakymu i svarbius klausimus vis dar nera, https://www.15min.lt/naujiena/aktualu/istorija/ dvidesimt-metu-po-pakaunes-savanoriu-maisto-582-357811 (dostęp: 12.09.2020).

Vitkus G., Diplomatine aporiją. Tarptautine Lietuvos ir Rusijos santykiu normalizacijos perspektyva, Vilnius 2007.

Zieliński J., Prezydent Republiki Litewskiej, w: Prezydent w państwach współczesnych, red. J. Osiński, Warszawa 2009, s. 357-400.

Krzysztof Buchowski, dr hab., prof. UwB; pracownik Wydziału Historii i Stosunków Miedzynarodowych Uniwersytetu w Białymstoku. Zainteresowania naukowe: historia Litwy i stosunków polsko-litewskich w XIX-XXI w. (k.buchowski@uwb.edu.pl).

Krzysztof Buchowski, dr hab., professor of the Univeristy of Bialystok, employed at the Faculty of History and International Relations. His research interests cover history of Lithuania and Polish-Lithuanian relations in the 19th-21st centuries (k.buchowski@uwb.edu.pl). 